\title{
The 2005 - 2007 Bala (Ankara, central Turkey) earthquakes: a case study for strike-slip fault terminations
}
K. ESAT ${ }^{1}$
B. ÇIVGIN²
B. KAYPAK ${ }^{2}$
V. IŞIK'
B. ECEVITOĞLU
G. SEYITOĞLU'

${ }^{1}$ Ankara University, Department of Geological Engineering, Tectonics Research Group TR-06100, Ankara, Turkey. Esat E-mail: Korhan.Esat@ankara.edu.tr. Phone: +90 31220334 00. Fax: +90 3122150487

${ }^{2}$ Ankara University, Department of Geophysical Engineering

TR-06100, Ankara, Turkey

${ }^{3}$ Anadolu University, Earth and Space Sciences Research Institute İki Eylül Campus, TR-26470, Eskişehir, Turkey

\begin{abstract}
An intense seismic activity has been observed after the Bala (Ankara, NW central Turkey) earthquakes (30 July 2005: $\mathrm{Mw}=5.3$, 20 December 2007: $\mathrm{Mw}=5.4$, and 26 December 2007: $\mathrm{Mw}=5.3$ ), continuing up to the present. The epicenters and the focal mechanism solutions of the earthquakes indicate that the right lateral strike-slip Afşar fault, trending $\mathrm{N} 55-60^{\circ} \mathrm{W}$, is responsible for the main shocks. The Afşar fault is thought to be the NW continuation of the Tuzgölü fault zone, which is one of the main neotectonic elements in central Anatolia. On the other hand, the aftershock distributions of the 2005 event have a NNE trend, and those of the 2007 event show a NW trending. Some focal mechanism solutions of the 2005 Bala earthquake aftershocks indicate normal and oblique normal faulting that corresponds to the NNE-trending Karakeçili fault. It seems that seismic activation of the NNE-trending Karakeçili fault was triggered by the 2005 main shock $(\mathrm{Mw}=5.3)$ that occurred on the NW-trending right lateral strike-slip Afşar fault. The overall neotectonic framework is that the northwestern edge of the Tuzgölü fault zone, represented by the Afşar fault in Bala, terminates in an extensional system represented by the oblique-slip Karakeçili fault.
\end{abstract}

KEYWORDS $\quad$ Strike-slip faults. Fault terminations. Tuzgölü fault zone. Neotectonics. Bala earthquake. Anatolia.

\section{INTRODUCTION}

The neotectonics of Turkey was evaluated in the context of plate tectonics (McKenzie, 1972). The neotectonic provinces have been delineated as the East Anatolian contractional province, the Central Anatolian "ova" province, and the West Anatolian extensional province (Şengör, 1979, 1980; Şengör et al., 1985). A cause-effect relationship for the development of the neotectonic provinces has been generally accepted, the triggering event of this relationship was the collision of the Eurasian and the Arabian plates along the Bitlis suture (Dewey et al., 1986). The collision was followed by the development of the North and East Anatolian fault zones, and by the subsequent westward motion of the Anatolian Plate, which created N-S extensional tectonics in western Turkey (Şengör, 1979, 1980; Şengör et al., 1985). However, Seyitoğlu and Scott $(1991,1996)$ argued that the initiation of extensional tectonics in western Turkey is older than the collision and therefore the cause-effect relationship is not 
a proper explanation for the development of the West Anatolian extensional province. The transition from the West Anatolian extensional province to the Central Anatolian "ova" province is roughly shown as a narrow N-S zone by McKenzie (1972) and Şengör et al. (1985). On the other hand, Barka and Reilinger (1997) indicate that the provinces are separated by the Eskişehir and Fethiye-Burdur fault zones (Fig. 1). The normal faultinduced earthquakes of 15 December 2000 Sultandağ $(\mathrm{Mw}=6.0)$ and 03 February 2002 Çay (Afyon) ( $\mathrm{Mw}=6.3$ ) (see Fig. 1 for location) (Taymaz and Tan, 2001; Başokur et al.., 2002; Emre et al.., 2003) changed the perception of the boundary between the western extensional province and that of central Anatolia
(Koçyiğit and Özacar, 2003). The contractional structures previously attributed to the intracontinental convergence in NW central Turkey (Koçyiğit, 1991; Koçyiğit et al., 1995) were now shown as neotectonic structures (i.e. Eldivan-Elmadağ Pinched Crustal Wedge) developed through an interaction between the North Anatolian fault zone and the Kirikkale-Erbaa fault zone (Seyitoğlu et al., 2000, 2009a).

The NE-SW trending right lateral Kirikkale-Erbaa fault zone and the NW-SE trending Tuzgölü fault zone converge in the Bala region, SE of Ankara (Fig. 1), where three significant earthquakes occurred on 30 July $2005(\mathrm{Mw}=5.3), 20$ December 2007

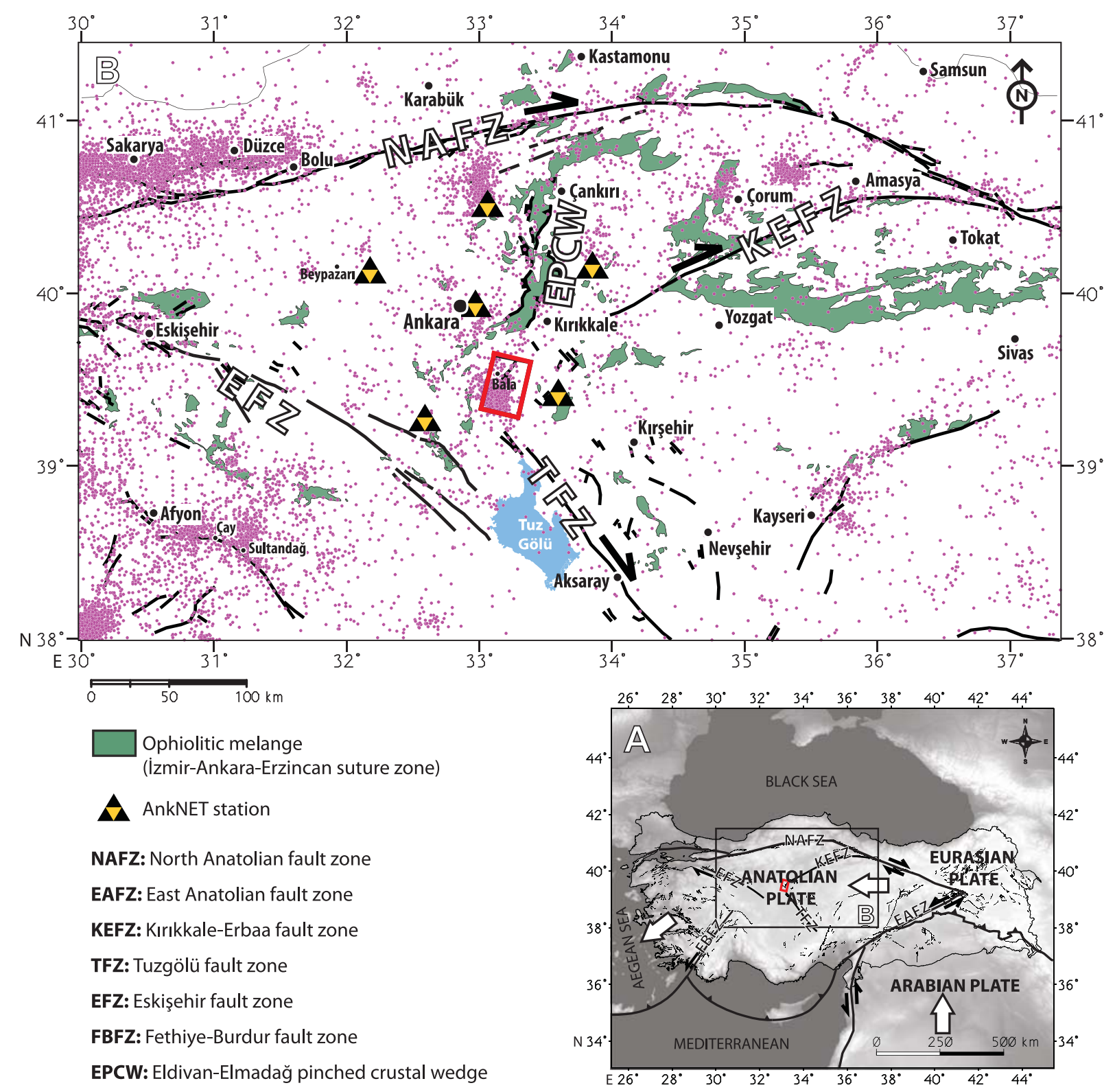

FIGURE 1 Major neotectonic elements of central Anatolia. The white arrows indicate relative plate motions. The red frame shows the study area. Pink dots represent earthquakes from 1900 to the present. Earthquake data were obtained from the Kandilli Observatory and Earthquake Research Institute of Turkey's catalogue. 
$(M w=5.4)$, and 26 December $2007(M w=5.3)$. After the 30 July 2005 main shock, intense earthquake activity was observed in the Bala region. This area corresponds to the NW tip of Tuzgölü fault zone and the main shocks and their aftershocks provide valuable information on the termination of strike-slip systems (Fig. 1).

\section{ACTIVE FAULTS AROUND BALA}

Active faults in the Bala region have been illustrated in unpublished reports (see Şaroğlu et al., 1987) and papers (Koçyiğit, 2003; Özsayın and Dirik, 2007; Rojay and Karaca, 2008; Koçyiğit, 2009; Tan et al., 2010). However, these studies lack detailed field observations and definitions of the actual faults.

The Afşar fault (ARF) and the Karakeçili fault (KKF) are two important active faults of the Bala region (Esat et al., 2009) (Fig. 2). It is easy to envisage the ARF as a continuation of the Tuzgölü fault zone due to its strike, but little is known about the KKF. This fault was previously called the Çatalören fault and interpreted as a left lateral conjugate of the ARF by Koçyiğit, $(2003,2009)$ and Tan et al. (2010). However, in other studies the KKF is described as a NNE-trending oblique-slip normal fault with a variable strike-slip component, bounding the Karakeçili NeogeneQuaternary basin (Türkmen and Özkul, 1999; Saraç, 2003). The $\mathrm{KKF}$ is composed of parallel and sub-parallel fault segments that involve basement rocks (mainly flysch and recrystallized limestone of Eocene age) and basin deposits (Neogene clastic sedimentary rocks, limestone, and gypsum). The slightly oblique normal fault surfaces and their slickensides are observed in the contact between the basement rocks and the sedimentary units (Fig. 3), and control the topography from the Bala highlands to the lower altitudes in the east (Fig. 4). Minor fracturing, breccias and veins, are common brittle features in the basement rocks in the vicinity of the faults. The fracturing is mainly defined by widespread joints. The joints are subvertical, quite linear and several meters long. Their spacing varies from 0.1 to $1 \mathrm{~m}$. They occur at either parallel or variable angles to the normal faults. Some of the fractures contain striae, suggesting a shear mode of fracturing. Veins along faults are evidence of fluid presence during deformation. They are up to $1 \mathrm{~m}$ wide and traceable for several meters. Their walls are sub-vertical, sharp and plane. The veins are composed of coarse-grained calcite crystals with blocky and elongate shape, and show brecciated textures. The orientation of veins is approximately $\mathrm{N}-\mathrm{S}$, similar to that of the successive normal fault scarps seen in the basin deposits.

In the hanging wall of the KKF at the west of Çatalçeşme village, the Quaternary (?) cover has normal fault scarps (Fig. 5A). Maximum displacement ranges from 0.75 to $1 \mathrm{~m}$, with slip dissipating towards the fault tip (Fig. 5B, C). The Çatalçeşme seismic reflection study has been performed in the fault scarps from this area (Fig. 5A, Appendix), and confirms the normal fault nature of the KKF. Most of the displacements seen on the Quaternary (?) cover can be traced in the subsurface (Fig. 6A, B).
The ARF has a right lateral strike-slip character and it is composed of many segments. The fault traces/surfaces cannot be easily recognized in the field because of intense agricultural overprint. However, the existence of the fault can be determined by careful reconnaissance in the field and by the use of satellite images. Most of the NW-trending segments of the ARF cause a variable right lateral displacement on the stream channels (Fig. 2; Fig. 7A, B). After the 2007 main shock, observations on the graveyard wall of Afşar town provided evidence of subsidiary strike-slip shear fractures. Using these fractures, the trend of the master fault can be estimated as $\mathrm{N} 25^{\circ} \mathrm{W}$, which is compatible with the en echelon fault segments determined by the deviations of the stream channels in the north of Afşar (Fig. 7C; Fig. 8). These deviations are coherent with the aftershock distribution towards the SE of Afşar. To test the trend of the master fault estimated from the subsidiary fractures on the graveyard wall, a seismic reflection study has been performed based on the morphological expression of the NW trending stream channels (Fig. 9, Appendix). In the Üç Ağıl seismic reflection section (Fig. $10 \mathrm{~A}, \mathrm{~B})$, the trace of the ARF is imaged just under the stream (Fig. 9). A typical positive flower structure is observed because the seismic section passes near the end of the segment that shifts toward NE, creating a local restraining stepover (Fig. 9).

\section{SEISMICITY}

Three significant earthquakes affected Ankara during the historical period (after 1900AD). The first one (I0=IX) occurred in an uncertain location among the cities of Ankara, Çankırı, and Çorum in AD 109 (Soysal et al., 1981). The other two occurred near the city of Ankara on 12 and 15 August 1668. The city center and the Beypazarı town were greatly damaged by these earthquakes (Ambraseys and Finkel, 1995).

In the instrumental period, a considerable number of earthquakes have occurred in central Anatolia affecting Ankara and its vicinity. Some larger than M>5.5 were: the 9 March 1902 Çankırı earthquake (Ms=5.6, I0=IX); the 19 April 1938 Kırşehir earthquake $(\mathrm{Mw}=6.4, \mathrm{I} 0=\mathrm{IX})$; the 1 February 1944 Gerede (Bolu) earthquake $(\mathrm{Mw}=6.8, \mathrm{I} 0=\mathrm{X})$; the 13 August 1951 Kurşunlu (Çankırı) earthquake (Mw=6.6, I0=IX); the 7 September 1953 Çerkeş (Çankırı) earthquake $(\mathrm{Mw}=6.0, \mathrm{I} 0=\mathrm{VII})$; and the 6 June 2000 Orta (Çankırı) earthquake $(\mathrm{Mw}=6.0)$.

The Bala region, $50 \mathrm{~km}$ to the SE of Ankara (Fig. 1), was seismically less active until July 2005, with only small earthquakes of magnitudes $\mathrm{M}<5$ (Fig. 11A). The largest events were the 4 July $1978(\mathrm{Mb}=4.9)$ and 21 April $1983(\mathrm{Mw}=4.7)$ earthquakes. No seismic activity was observed in the region between April 1983 and July 2005.

An earthquake with a magnitude of $\mathrm{Mw}=5.3$ occurred at a depth of about $6 \mathrm{~km}$ near the town of Bala on 30 July 2005 


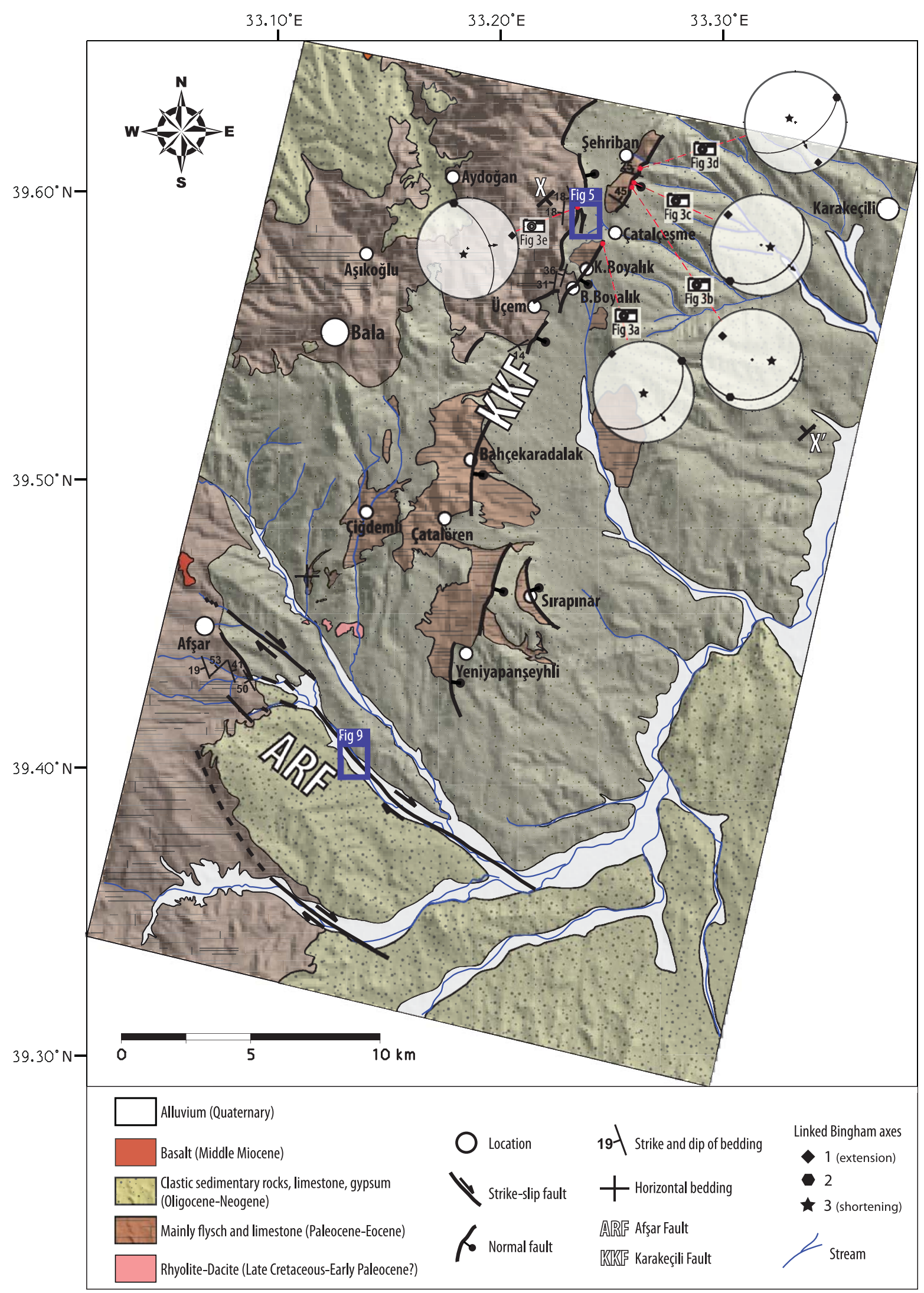

FIGURE 2 Geological map of the Bala area. White circles show the lower hemisphere equal-area stereographic projections of the fault planes. The map is based on our field observations, the ASTER satellite image, and geological maps in Erol (1954) and Akçay et al. (2008). 

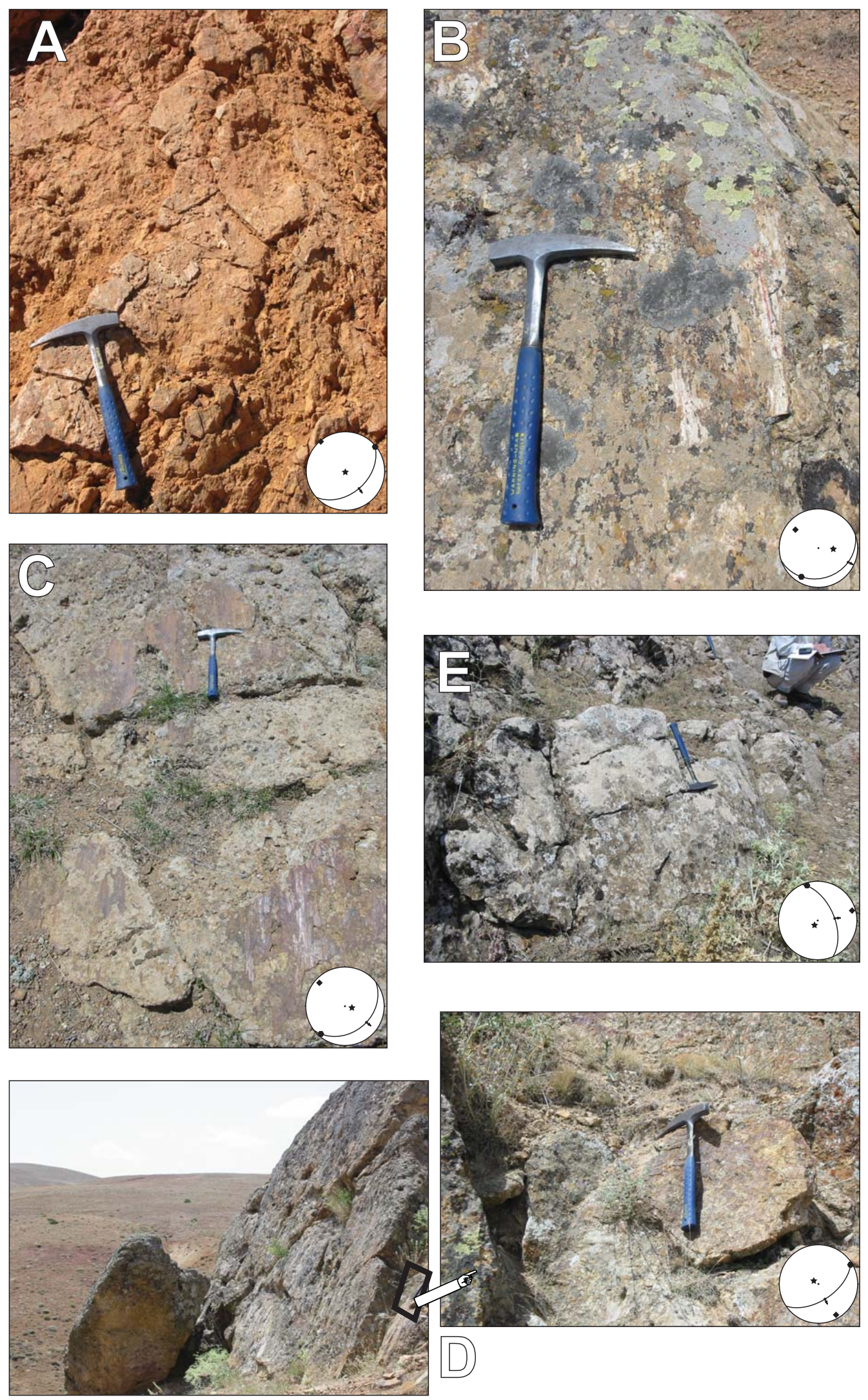

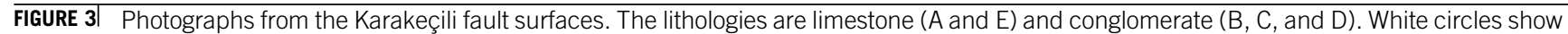
the lower hemisphere equal-area stereographic projections of the fault planes. See Figure 2 for the locations. 


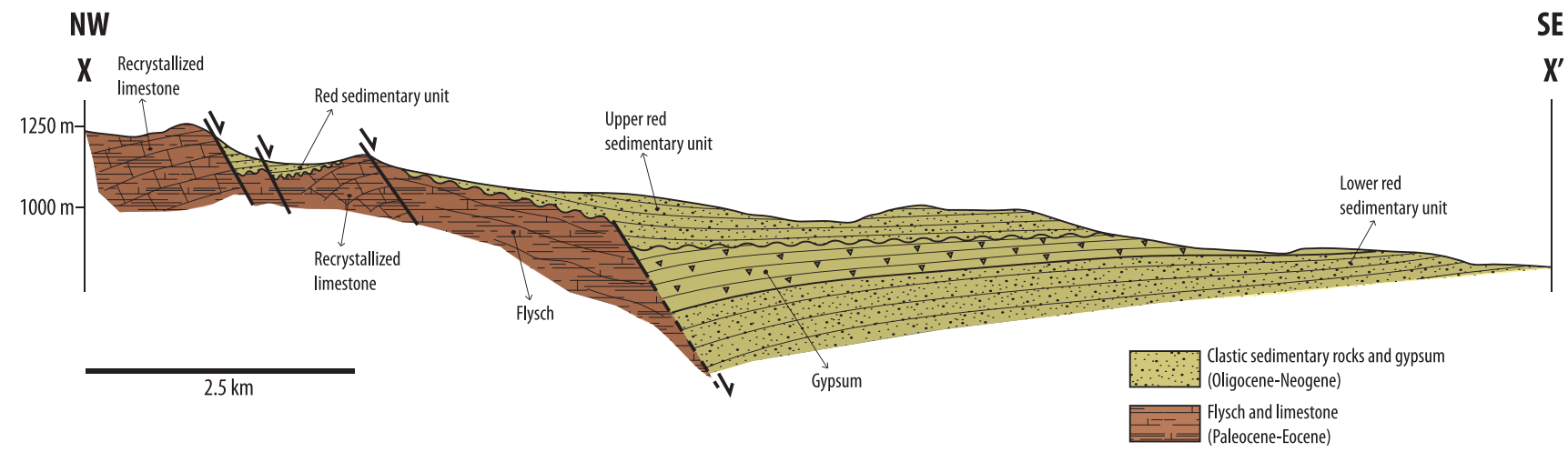

\begin{tabular}{l|l}
\hline FIGURE 4 & Geological cross-section showing the inner structure of the Karakeçili Neogene-Quaternary basin. See Figure 2 for the cross-section line.
\end{tabular}
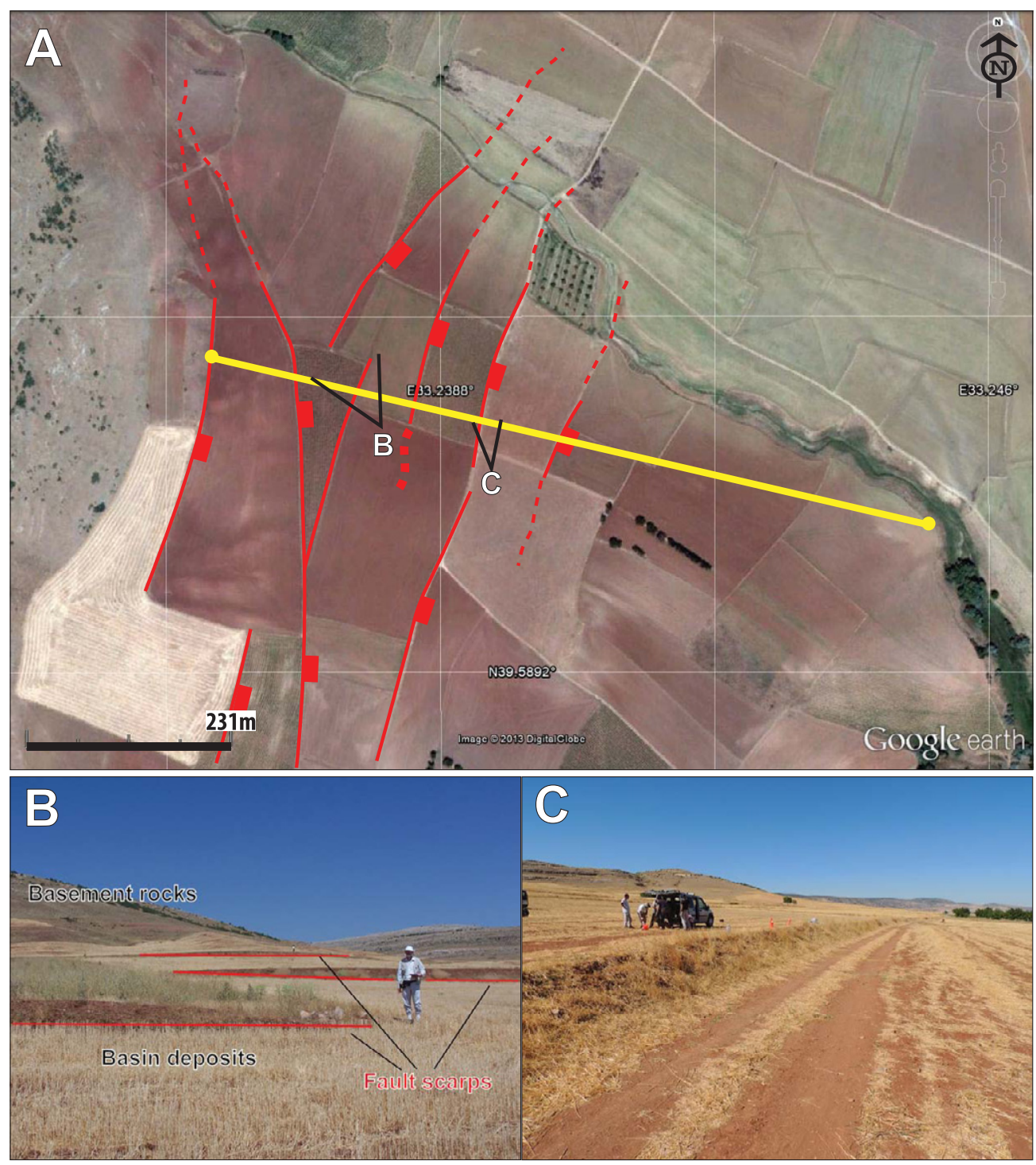

FIGURE 5 A) Detailed map of normal fault traces of the Karakeçili fault. Red lines represent the actual fault scarps within the Quaternary (?) units and yellow line shows the location of a seismic reflection study on the KKF. B) Field photo of the normal fault scarps. C) Normal fault scarp and trace of the seismic reflection profile. See Figure 2 for location. 
TABLE 1 1 Parameters of the focal mechanism solutions related to the Af ar and Karakeçili Faults. Solution of the 04.07.1978 (Mb=4.9) earthquake is provided by Kocaefe and Ataman (1982). Solutions of the 30.07.2005 (Mw=5.3) and the 20.12.2007 (Mw=5.4) Bala earthquakes and their large aftershocks are provided by this study

\begin{tabular}{|c|c|c|c|c|c|c|c|c|c|c|c|c|c|}
\hline \multirow[b]{2}{*}{$\mathrm{N}^{\circ}$} & \multirow[b]{2}{*}{$\begin{array}{c}\text { Date } \\
\text { (dd/mm/yy) }\end{array}$} & \multirow[b]{2}{*}{$\begin{array}{c}\text { Time } \\
\text { (UTC) }\end{array}$} & \multirow[b]{2}{*}{$\begin{array}{l}\text { Latitude } \\
\mathrm{N}\left({ }^{\circ}\right)\end{array}$} & \multirow[b]{2}{*}{$\begin{array}{c}\text { Longitude } \\
\mathrm{E}\left({ }^{\circ}\right)\end{array}$} & \multirow[b]{2}{*}{$\begin{array}{l}\text { Depth } \\
(\mathrm{km})\end{array}$} & \multirow[b]{2}{*}{ Magnitude } & \multicolumn{3}{|c|}{ Nodal Planes } & \multicolumn{2}{|c|}{$P$} & \multicolumn{2}{|l|}{$\mathrm{T}$} \\
\hline & & & & & & & $\begin{array}{l}\text { Strike1 }\left(^{\circ}\right) \\
\text { Strike2( }\left(^{\circ}\right)\end{array}$ & $\begin{array}{l}\operatorname{Dip} 1\left(^{\circ}\right) \\
\left.\operatorname{Dip} 2^{\circ}\right)\end{array}$ & $\begin{array}{l}\operatorname{Rake1}\left({ }^{\circ}\right) \\
\operatorname{Rake2}\left(^{\circ}\right)\end{array}$ & $\begin{array}{c}\text { Azimuth } \\
\left({ }^{\circ}\right)\end{array}$ & $\begin{array}{c}\text { Plunge } \\
\left({ }^{\circ}\right)\end{array}$ & $\begin{array}{l}\text { Azimuth } \\
\left({ }^{\circ}\right)\end{array}$ & $\begin{array}{c}\text { Plunge } \\
\left({ }^{\circ}\right)\end{array}$ \\
\hline 1 & $04 / 07 / 78$ & $22: 39: 16$ & 39.450 & 33.190 & 23 & $4.9(\mathrm{Mb})$ & $\begin{array}{l}303 \\
186\end{array}$ & $\begin{array}{l}66 \\
44\end{array}$ & $\begin{array}{r}-129 \\
-36\end{array}$ & 167 & 54 & 59 & 13 \\
\hline 2 & $30 / 07 / 05$ & $21: 45: 01$ & 39.4061 & 33.1384 & 6.391 & $5.3(\mathrm{Mw})$ & $\begin{array}{l}301 \\
207\end{array}$ & $\begin{array}{l}70 \\
80\end{array}$ & $\begin{array}{r}-169 \\
-21\end{array}$ & 162 & 22 & 255 & 7 \\
\hline 3 & $31 / 07 / 05$ & $00: 14: 48$ & 39.4213 & 33.1497 & 10.869 & $3.2\left(\mathrm{M}_{\mathrm{D}}\right)$ & $\begin{array}{l}343 \\
180\end{array}$ & $\begin{array}{l}61 \\
30\end{array}$ & $\begin{array}{l}-98 \\
-75\end{array}$ & 223 & 73 & 79 & 16 \\
\hline 4 & $31 / 07 / 05$ & $00: 45: 14$ & 39.4141 & 33.1392 & 6.463 & $3.9(\mathrm{Mw})$ & $\begin{array}{l}129 \\
278\end{array}$ & $\begin{array}{l}48 \\
47\end{array}$ & $\begin{array}{r}-68 \\
-113\end{array}$ & 112 & 74 & 204 & 0 \\
\hline 5 & $31 / 07 / 05$ & 01:09:21 & 39.4358 & 33.1515 & 5.149 & $3.3\left(\mathrm{M}_{\mathrm{D}}\right)$ & $\begin{array}{r}57 \\
217\end{array}$ & $\begin{array}{l}56 \\
34\end{array}$ & $\begin{array}{r}-79 \\
-107\end{array}$ & 1 & 75 & 139 & 11 \\
\hline 6 & $31 / 07 / 05$ & $15: 18: 19$ & 39.4370 & 33.0570 & 17.6 & $4.5(\mathrm{Mw})$ & $\begin{array}{l}212 \\
304\end{array}$ & $\begin{array}{l}79 \\
78\end{array}$ & $\begin{array}{r}-12 \\
-168\end{array}$ & 168 & 16 & 258 & 0 \\
\hline 7 & $31 / 07 / 05$ & $15: 23: 25$ & 39.4240 & 33.0530 & 12.2 & $4.1(\mathrm{Mw})$ & $\begin{array}{l}296 \\
205\end{array}$ & $\begin{array}{l}87 \\
73\end{array}$ & $\begin{array}{r}-163 \\
-4\end{array}$ & 162 & 14 & 70 & 9 \\
\hline 8 & $31 / 07 / 05$ & $23: 41: 35$ & 39.3897 & 33.1146 & 8.258 & $4.6(\mathrm{Mw})$ & $\begin{array}{l}285 \\
177\end{array}$ & $\begin{array}{l}66 \\
55\end{array}$ & $\begin{array}{r}-141 \\
-30\end{array}$ & 145 & 44 & 49 & 7 \\
\hline 9 & $01 / 08 / 05$ & $00: 45: 07$ & 39.4062 & 33.0885 & 12.182 & $4.4(\mathrm{Mw})$ & $\begin{array}{r}96 \\
2\end{array}$ & $\begin{array}{l}85 \\
46\end{array}$ & $\begin{array}{r}-136 \\
-6\end{array}$ & 329 & 33 & 221 & 26 \\
\hline 10 & $06 / 08 / 05$ & 09:09:27 & 39.352 & 33.103 & 6.8 & $4.2(\mathrm{Mw})$ & $\begin{array}{l}282 \\
187\end{array}$ & $\begin{array}{l}82 \\
64\end{array}$ & $\begin{array}{r}-154 \\
-9\end{array}$ & 148 & 24 & 52 & 12 \\
\hline 11 & $20 / 12 / 07$ & $07: 36: 49$ & 39.4123 & 33.0807 & 3.799 & $3.6(\mathrm{Mw})$ & $\begin{array}{r}138 \\
47\end{array}$ & $\begin{array}{l}87 \\
67\end{array}$ & $\begin{array}{r}-157 \\
-4\end{array}$ & 5 & 18 & 270 & 13 \\
\hline 12 & $20 / 12 / 07$ & $09: 48: 28$ & 39.4107 & 33.0942 & 3.963 & $5.4(\mathrm{Mw})$ & $\begin{array}{r}113 \\
22\end{array}$ & $\begin{array}{l}85 \\
79\end{array}$ & $\begin{array}{r}-169 \\
-5\end{array}$ & 338 & 11 & 247 & 4 \\
\hline 13 & $21 / 12 / 07$ & $21: 44: 49$ & 39.3997 & 33.1271 & 5.42 & $3.0(\mathrm{Mw})$ & $\begin{array}{l}177 \\
280\end{array}$ & $\begin{array}{l}70 \\
59\end{array}$ & $\begin{array}{r}-33 \\
-156\end{array}$ & 135 & 37 & 230 & 7 \\
\hline 14 & $26 / 12 / 07$ & $23: 47: 09$ & 39.4135 & 33.0803 & 4.516 & $5.3(\mathrm{Mw})$ & $\begin{array}{r}154 \\
54\end{array}$ & $\begin{array}{l}65 \\
70\end{array}$ & $\begin{array}{r}-158 \\
-27\end{array}$ & 13 & 33 & 105 & 3 \\
\hline 15 & $27 / 12 / 07$ & 07:47:01 & 39.4550 & 33.0470 & 5.073 & $4.3(\mathrm{Mw})$ & $\begin{array}{l}157 \\
248\end{array}$ & $\begin{array}{l}81 \\
88\end{array}$ & $\begin{array}{r}178 \\
9\end{array}$ & 22 & 5 & 113 & 8 \\
\hline 16 & $27 / 12 / 07$ & $13: 47: 58$ & 39.4398 & 33.0640 & 5.064 & $4.4(\mathrm{Mw})$ & $\begin{array}{r}25 \\
174\end{array}$ & $\begin{array}{l}44 \\
50\end{array}$ & $\begin{array}{r}-67 \\
-111\end{array}$ & 21 & 74 & 279 & 3 \\
\hline 17 & $27 / 12 / 07$ & $17: 56: 12$ & 39.4039 & 33.1035 & 6.042 & $3.7(\mathrm{Mw})$ & $\begin{array}{r}24 \\
143\end{array}$ & $\begin{array}{l}48 \\
62\end{array}$ & $\begin{array}{r}-40 \\
-130\end{array}$ & 2 & 54 & 261 & 8 \\
\hline 18 & $11 / 01 / 08$ & $16: 07: 49$ & 39.4406 & 33.0454 & 7.583 & $3.5(\mathrm{Mw})$ & $\begin{array}{r}145 \\
46\end{array}$ & $\begin{array}{l}70 \\
66\end{array}$ & $\begin{array}{r}-154 \\
-22\end{array}$ & 6 & 32 & 275 & 3 \\
\hline
\end{tabular}

(21:45:0.96 UTC). Following the main shock, a number of aftershocks were observed in the region (Fig. 11B). Fig. 12A shows the aftershock distribution within one month after the main shock. The focal parameters of the main shock and of the largest aftershocks are given in Table 1 .

After the 30 July 2005 earthquake a project was launched in January 2007 by the Tectonics Research Group of Ankara University, to investigate the internal deformation of the Anatolian Plate around Ankara. Within the scope of this project, the Earthquake Monitoring Network of Ankara University (AnkNET) was established in September 2007 to record the earthquake activity around Ankara (Fig. 1). It consists of six Güralp 6TD broad-band type seismometers (Seyitoğlu et al., 2009b).

A large event of $\mathrm{Mw}=5.4$ occurred in the Bala region on 20 December 2007 (UTC: 09:48:28.17). Six days later, on 26 December 2007 (UTC: 23:47:09.39), a large aftershock $(\mathrm{Mw}=5.3)$ shook the region. A time histogram of the events following the 20 December 2007 main shock is shown in Fig. 12B. Some large aftershocks that occurred after the 20 December 2007 main shock are given in Table 1 .

\section{Location and re-location process}

The waveform data for the 30 July 2005 earthquake and its aftershocks were obtained from the Kandilli Observatory and Earthquake Research Institute of Turkey (KOERI). Nearly 100 events, recorded in high quality by at least 5 stations, were selected from almost 320 , and all $\mathrm{P}$ and $\mathrm{S}$ phases were re-picked before the relocation process. The data of the 20 December 2007 earthquake and its aftershock were collected by the AnkNET. 593 well recorded events were selected for phase picking.

The initial location of all events was performed using the double-difference hypocenter location method developed by Waldhauser and Ellsworth (2000) using the HYPODD algorithm 

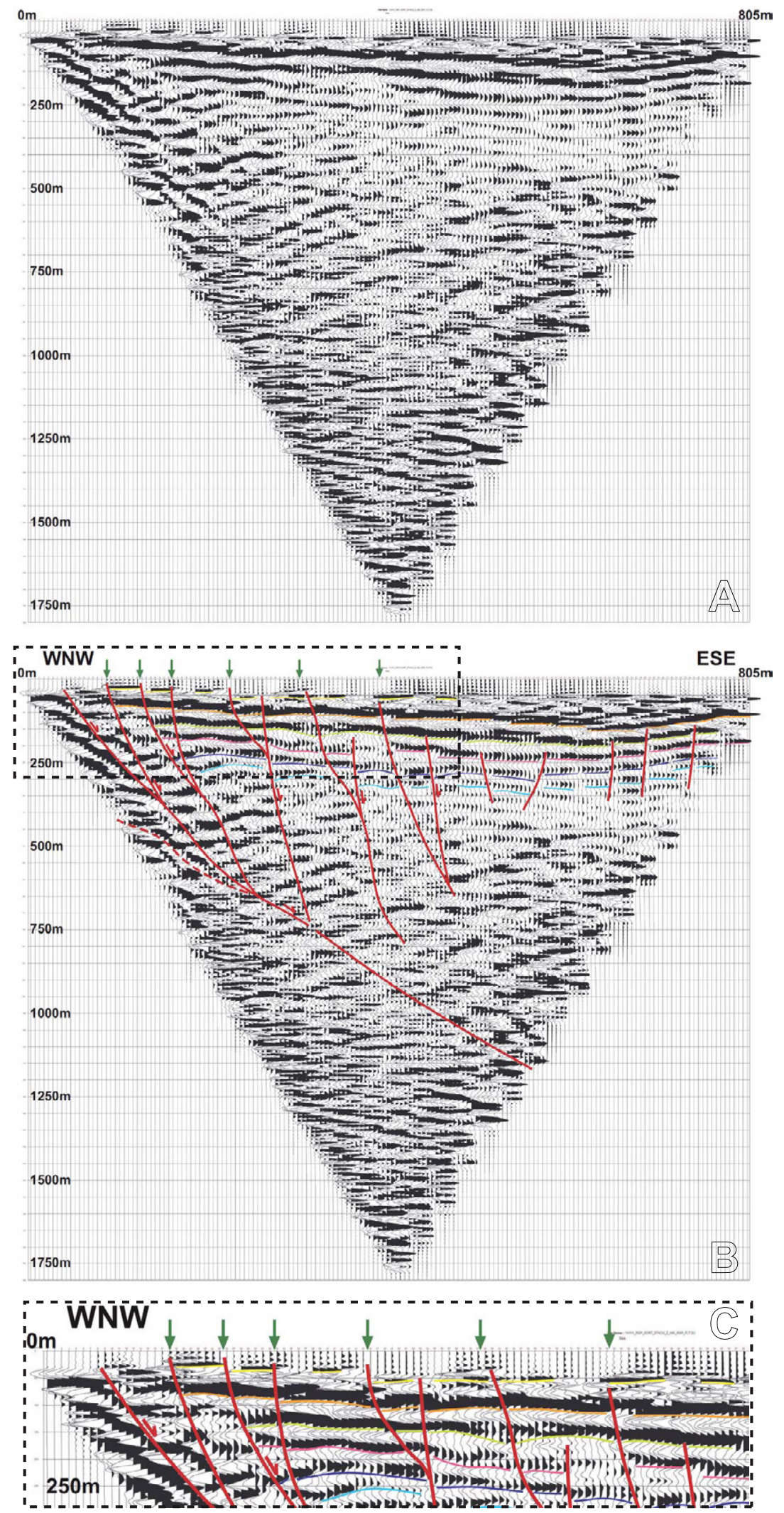

FIGURE 6l Çatalçeşme seismic reflection section on the KKF. A) Uninterpreted. B) Interpreted (green arrows represent Quaternary (?) fault scarps' locations); red lines represent the faults. C) Close up view of the area within the frame in Figure 6B. 


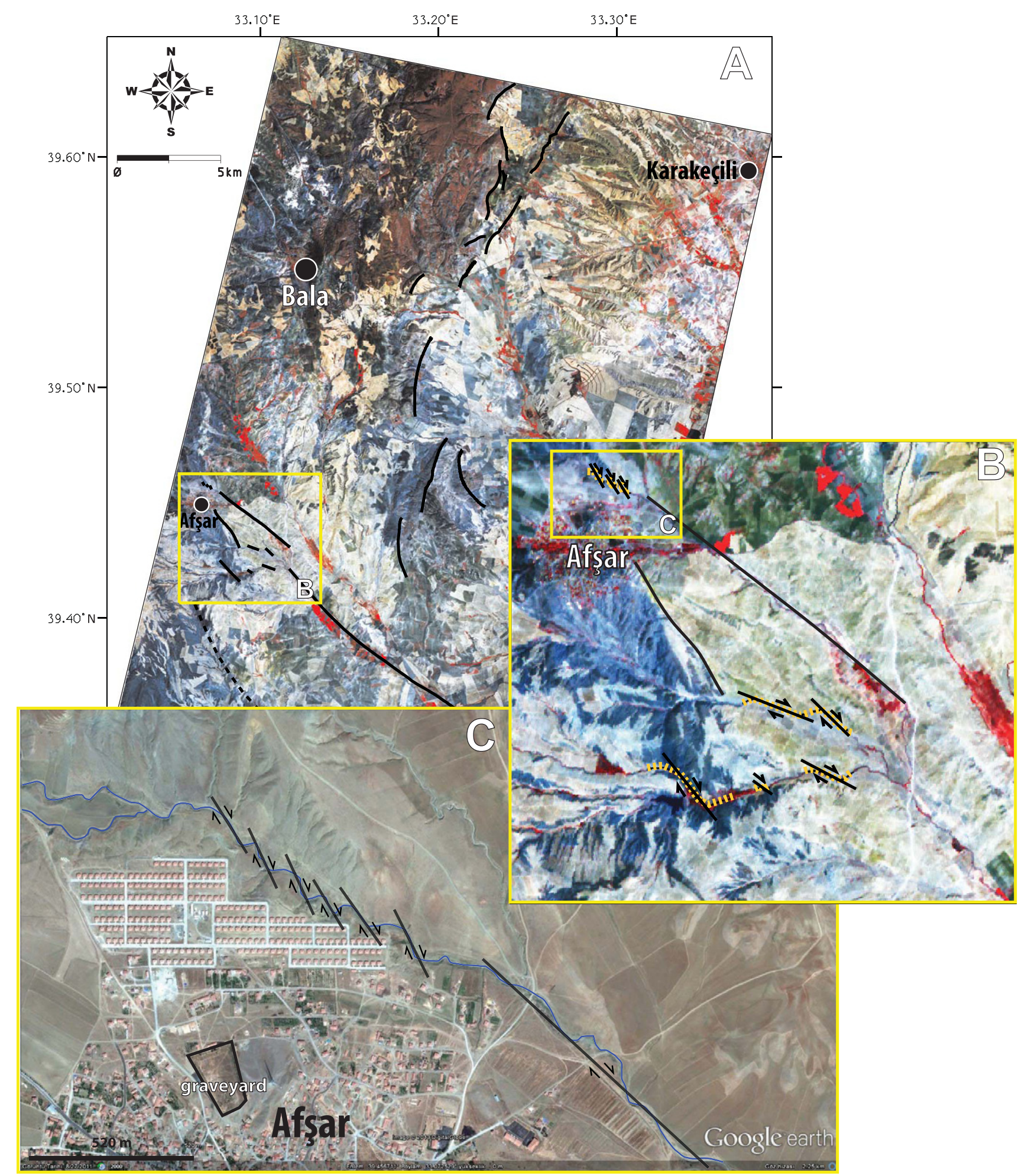

FIGURE 7 A) ASTER satellite image of the study area. The black lines represent faults. B) Close up view of the Afsar area; the arrows show displacement directions of the streams. C) Google Earth satellite image; systematic right lateral displacements of the stream are observed north of the graveyard. 

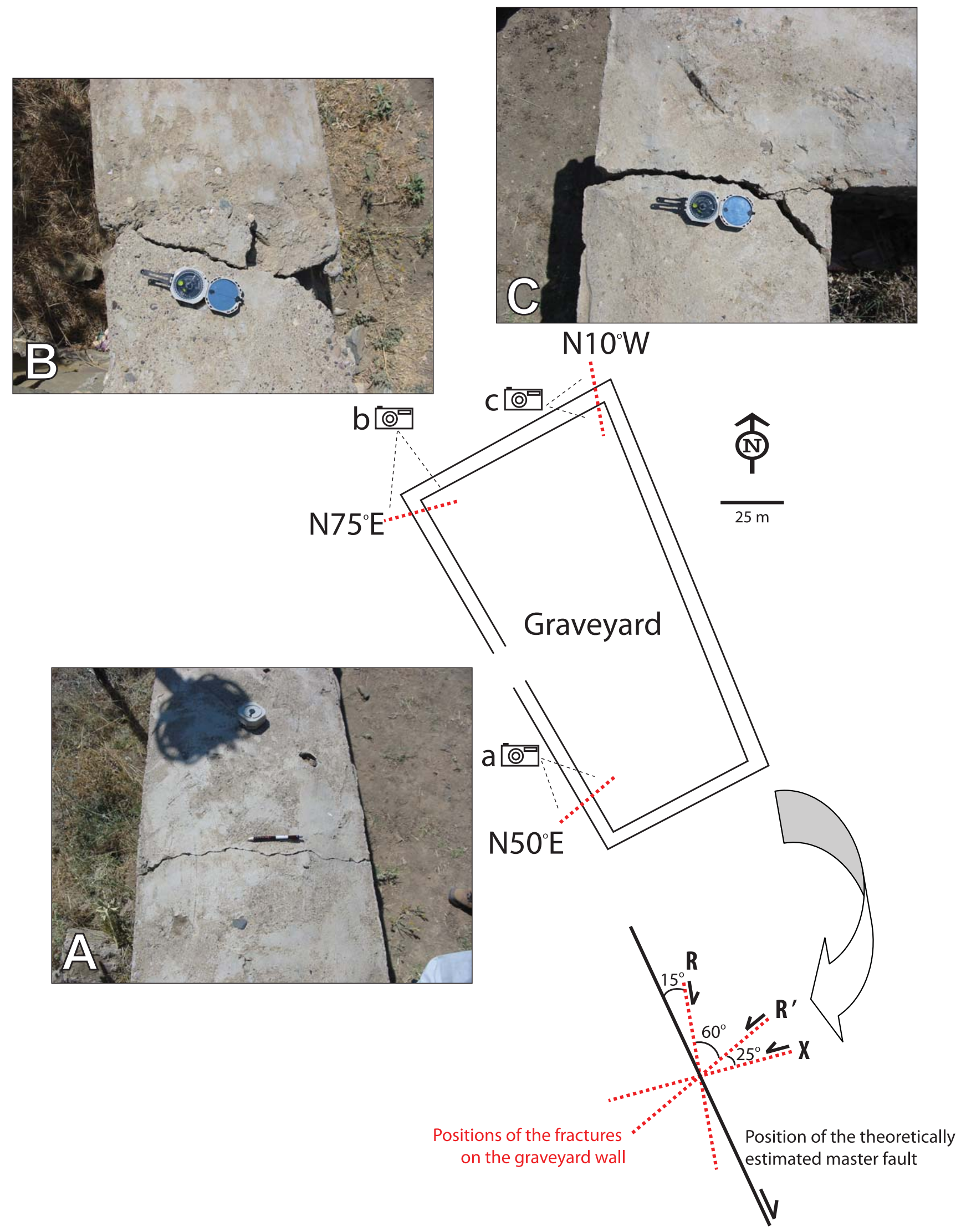

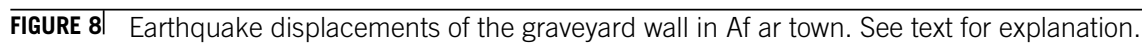


of Waldhauser (2001). In the initial location processes, we used a simple P- and S-wave velocity model (Toksöz et al., 2003) corresponding to the central Anatolian crustal structure. Çıvgin and Kaypak (2012) estimated a new 1D velocity model for the region by using these initial locations and $2955 \mathrm{P}$ - and S-seismic wave phases. This new model (Table 2) was used for relocation of the events.

The main shock location and aftershock distribution for the 30 July 2005 and 20 December 2007 earthquakes are shown in Fig. 13A and Fig. 14A, respectively. The aftershock distribution of the 30 July 2005 earthquake has a NNE-SSW trend on the KKF (Fig. 13A), the epicentral locations of the 20 December 2007 earthquake and its aftershocks have a NW-SE trend on the ARF (Fig. 14A).

\section{Depth sections}

The aftershock hypocenters of the 2005 main shock are distributed in the upper $35 \mathrm{~km}$ and they are concentrated in the
TABLE 2 Crustal 1D velocity model used in relocation (Çıvgın and Kaypak, 2012)

\begin{tabular}{lrr}
\hline $\begin{array}{l}\text { Depth of layer } \\
\text { boundaries }(\mathrm{km})\end{array}$ & $\mathrm{Vp}(\mathrm{km} / \mathrm{s})$ & $\mathrm{Vs}(\mathrm{km} / \mathrm{s})$ \\
\hline $00.0-08.0$ & 5.25 & 3.02 \\
$08.0-13.0$ & 5.82 & 3.38 \\
$13.0-19.0$ & 6.06 & 3.48 \\
$19.0-30.0$ & 6.15 & 3.48 \\
$30.0-31.0$ & 6.47 & 3.75 \\
$31.0-32.0$ & 6.53 & 3.78 \\
$32.0-33.0$ & 6.55 & 3.79 \\
$33.0-34.0$ & 6.69 & 3.89 \\
$34.0-35.0$ & 6.73 & 3.91 \\
$35.0-36.0$ & 6.85 & 3.99 \\
$36.0-\ldots$ & 7.10 & 4.08 \\
\hline
\end{tabular}

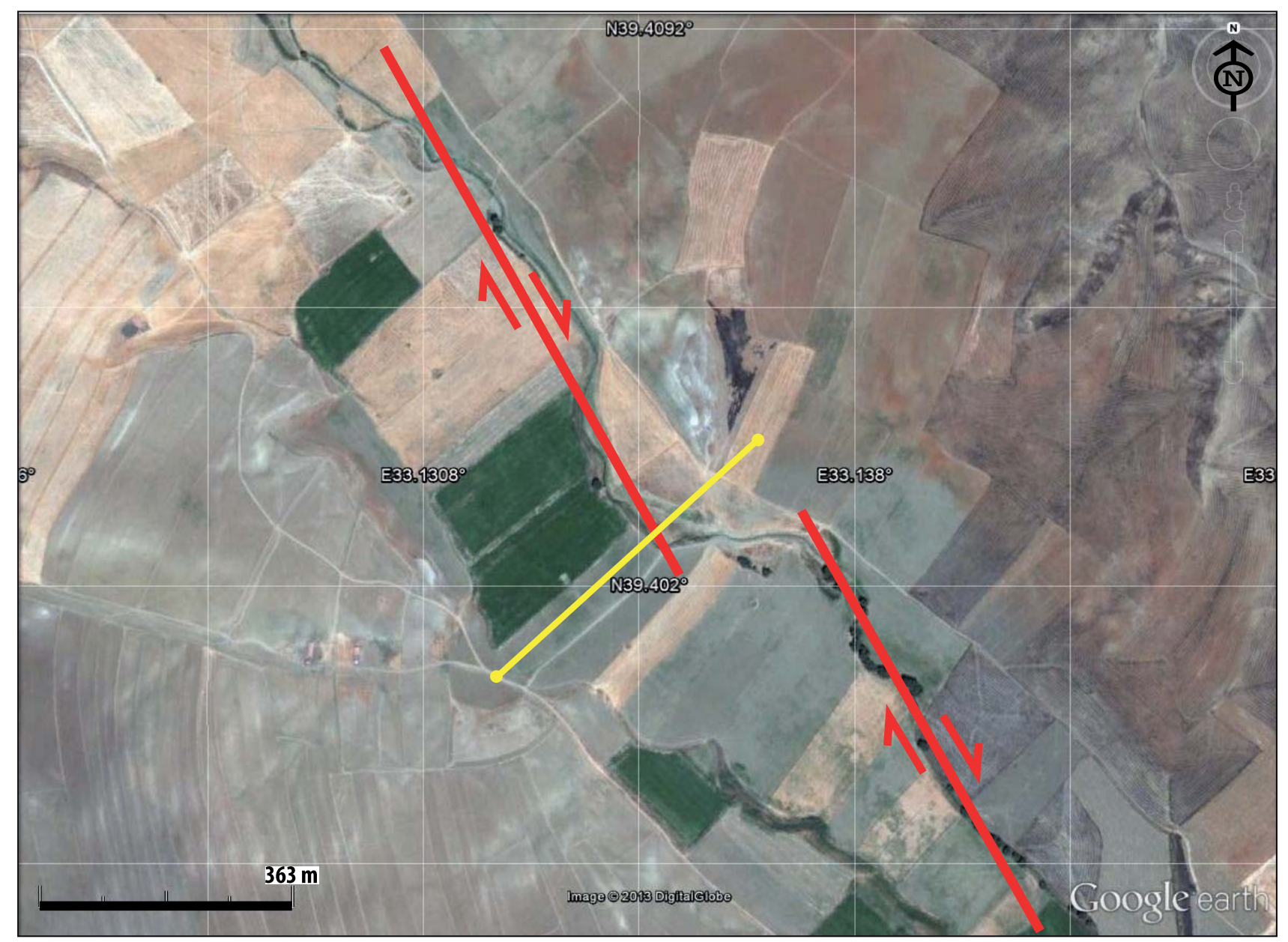

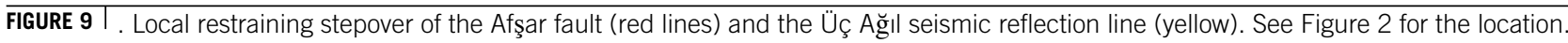


$0 \mathrm{~m}$

$487.5 \mathrm{~m}$
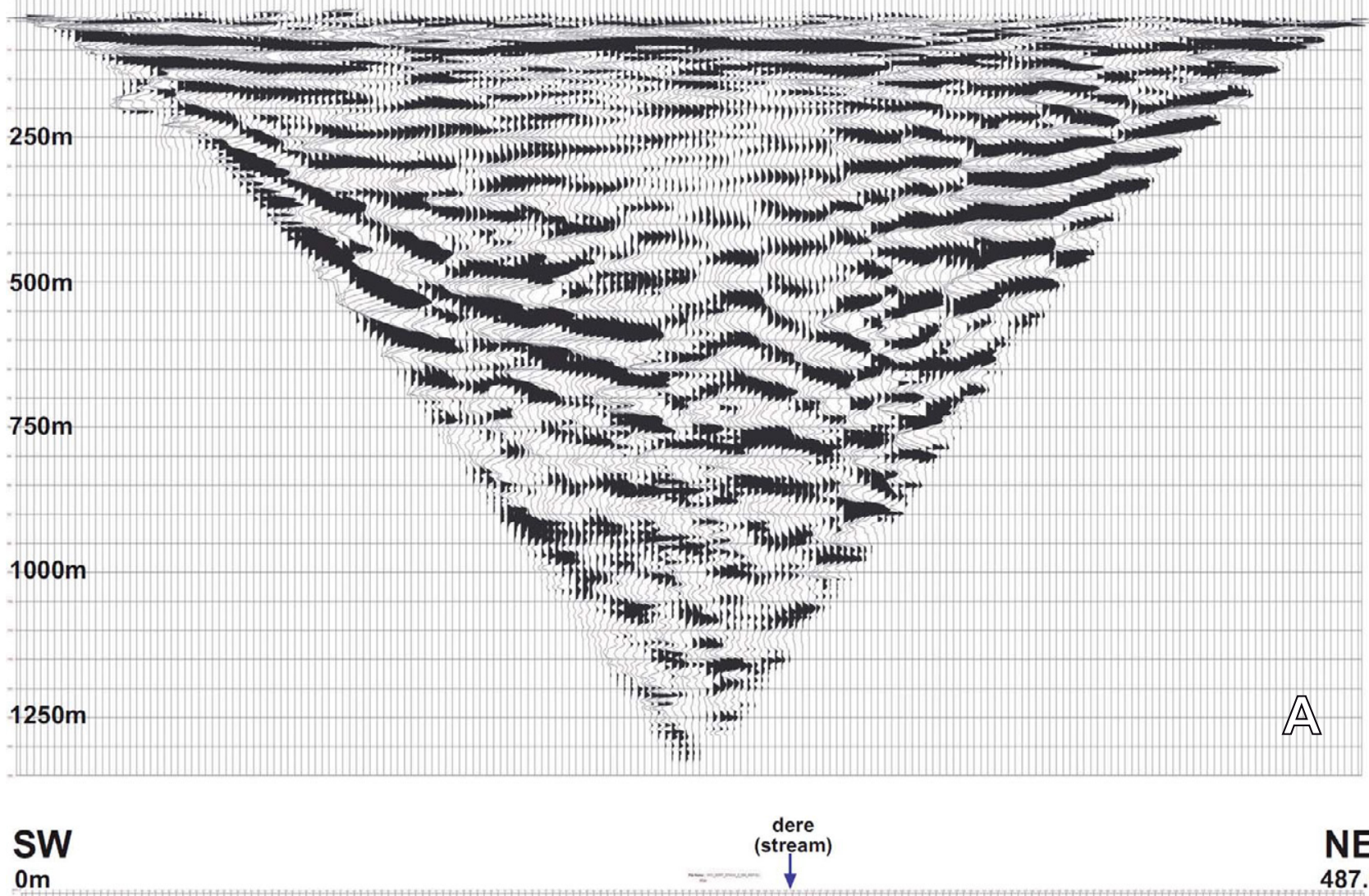

NE

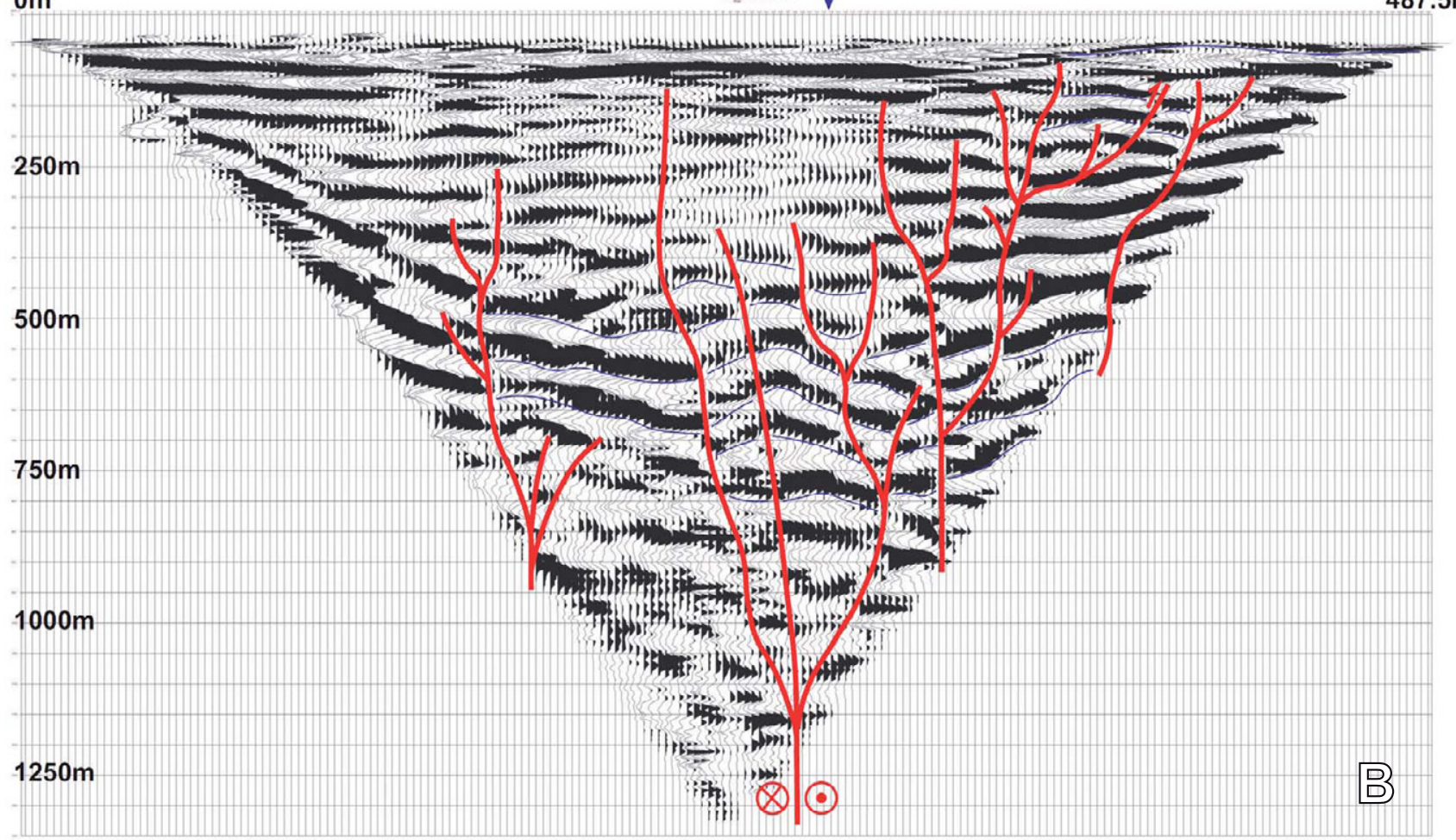

FIGURE 10 | Üç Ağıl seismic reflection section on the Afşar fault. A) Uninterpreted. B) Interpreted. Red lines represent faults. 

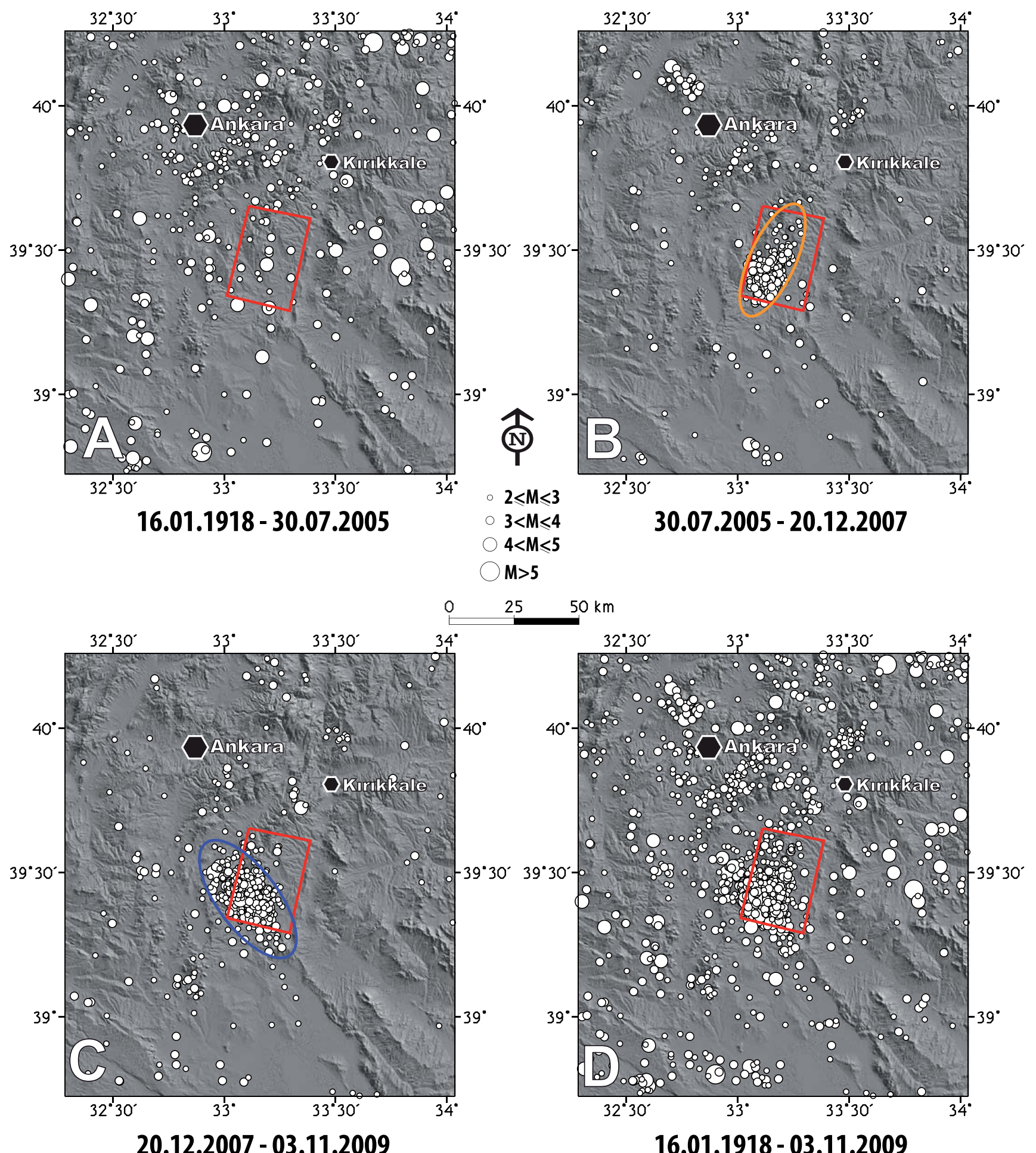

FIGURE 11 The earthquake activity between 16 January 1918 and 03 November 2009. The red frame shows the study area. The ellipses represent the earthquake clustering. Earthquake data were obtained from the Kandilli Observatory and Earthquake Research Institute of Turkey's catalogue. 
upper $10 \mathrm{~km}$ (Fig. 13B). However, the earthquakes in the NE of the region are mostly below $10 \mathrm{~km}$ depth (Fig. 13B, A-A $\square$ and D-D $\square$ sections). It can be interpreted that the KKF has an E-SE dipping geometry based on the distribution in the D-D $\square$ section which is perpendicular to it (Fig. 13B).

On the other hand, almost all aftershocks hypocenters of the 2007 main shock are above 12km depth (Fig. 14B). The depth sections perpendicular to the ARF show that the hypocenters are aligned in a narrow zone of about $4 \mathrm{~km}$ (Fig. 14B, F-F $\square$ and G-G $\square$ sections). This aftershock distribution is compatible with the strike-slip nature of ARF.

\section{Focal mechanism solutions}

Focal mechanism solutions for both main shocks and their significant aftershocks were determined by a full waveform moment tensor inversion method which was developed and extended to full waveform data at regional or local distances by Zahradnik et al. (2005), based on Kikuchi and Kanamori (1991). For the computation of the earthquake source parameters, we used MATLAB based software called ISOLA-GUI, developed by Sokos and Zahradnik (2008). During the waveform inversion, the same one-dimensional velocity model was used for all focal mechanism solutions.

The focal mechanism solutions of the 2005 and the 2007 earthquakes and of their large aftershocks are shown in Fig. 13A and Fig. 14A, respectively. Their source parameters are summarized in Table 1. Besides, the focal mechanism solution of the 4 July $1978(\mathrm{Mb}=4.9)$ earthquake obtained from P-wave first

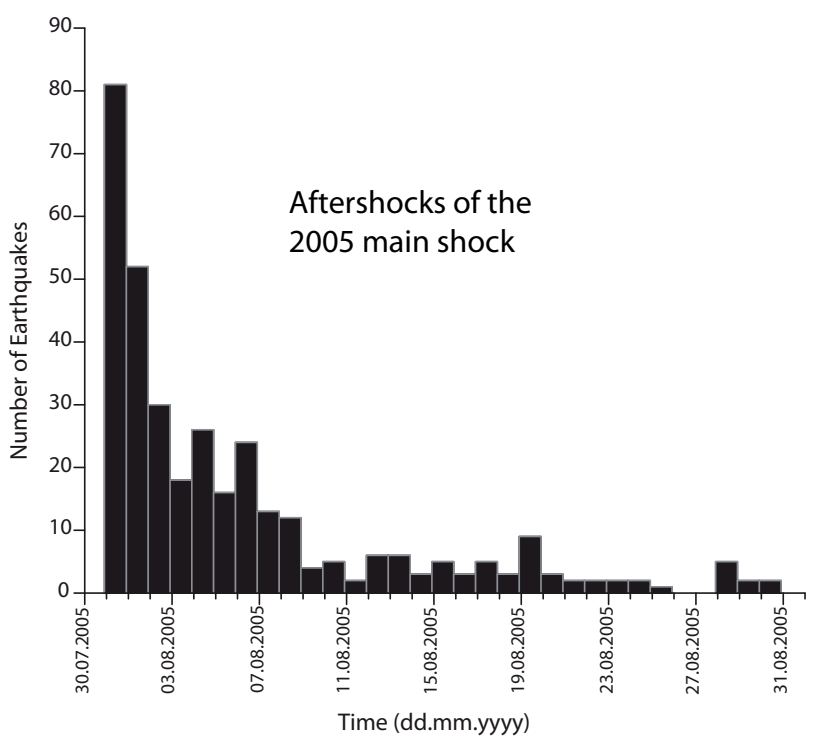

A motion polarities by Kocaefe and Ataman (1982) is given in Fig. 13A and Table 1. This event is located on the KKF and indicates oblique-slip normal faulting (Fig. 13A; Table 1).

\section{FAULT SLIP ANALYSIS}

Fault slip data obtained from nodal planes of the focal mechanism solutions and from field observations in the Bala region have been analysed (Table 3). One of the two nodal planes of each focal mechanism solutions has been selected as the actual fault, based on the observation of fault orientations in the field. FaultKin software was used for the analysis (see Marrett and Allmendinger (1990); Rowland et al. (2007) for theoretical background of kinematic compatibility). The analysis of the overall data shows that the shortening axis is almost vertical and the extension axis is nearly horizontal. Linked Bingham axes represent these strain axes. According to this strain orientation, the extension axis indicates an extension direction of $\mathrm{N} 81^{\circ} \mathrm{E}$ in the region (Fig. 15A). Moreover, the uniform direction of the contoured diagrams of the shortening $(\mathrm{P})$ and the extension $(\mathrm{T})$ axes shows that the faults (KKF and ARF) are kinematically compatible (Fig. 15B, C).

\section{DISCUSSION AND CONCLUSIONS}

After the main shock on 30 July 2005 through 2009, earthquake clusters with NNE-SSW and NW-SE directions have been recorded. The aftershocks from the 30 July 2005 main shock have a NNE-SSW direction (Fig. 11B; Fig. 13A), and the 20

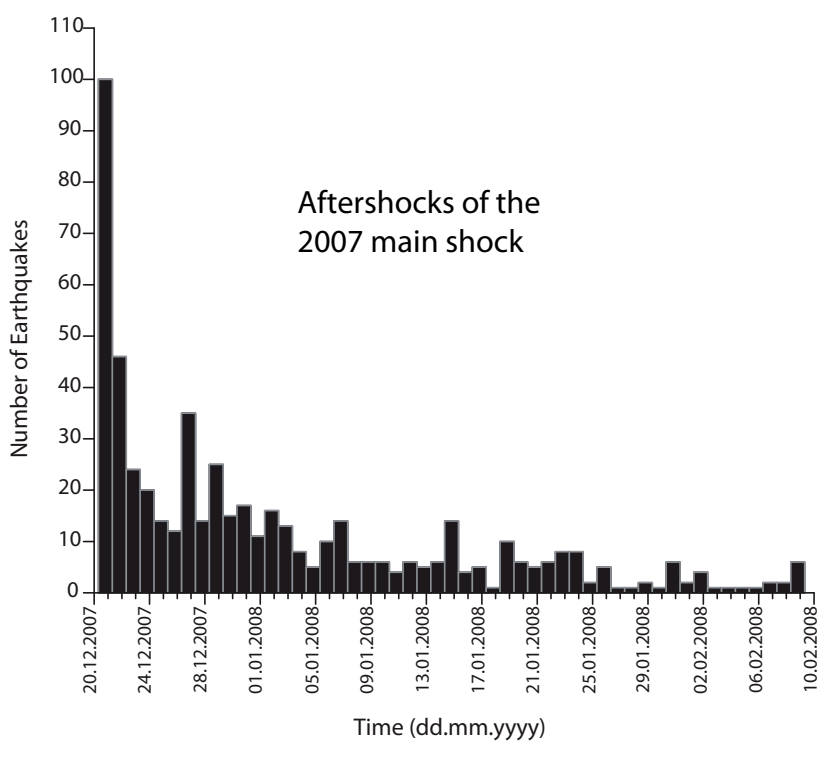

B

FIGURE 12 | Histograms showing the number and distribution of aftershocks after the A) 2005 main shock and B) 2007 main shock. 


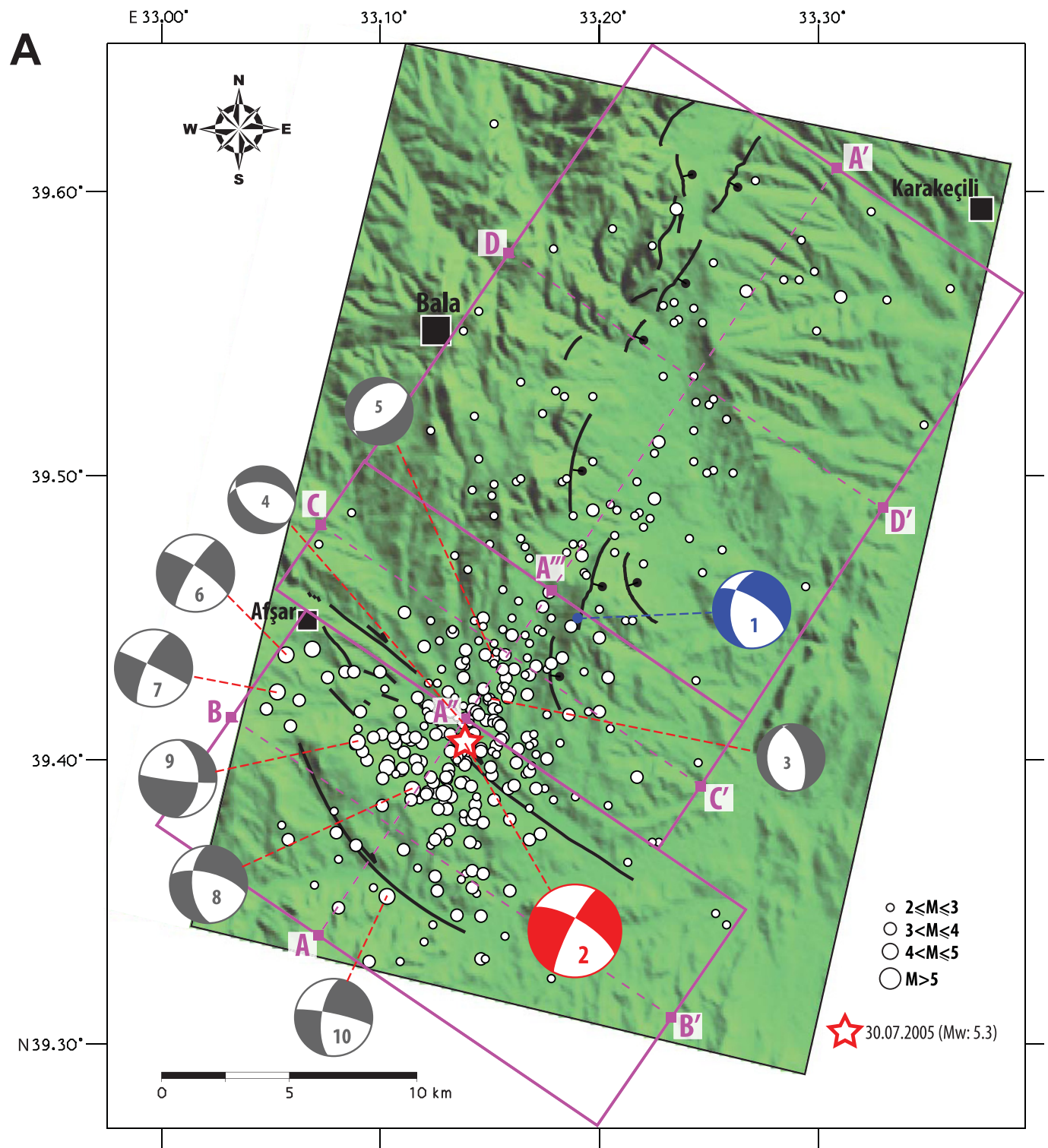

B

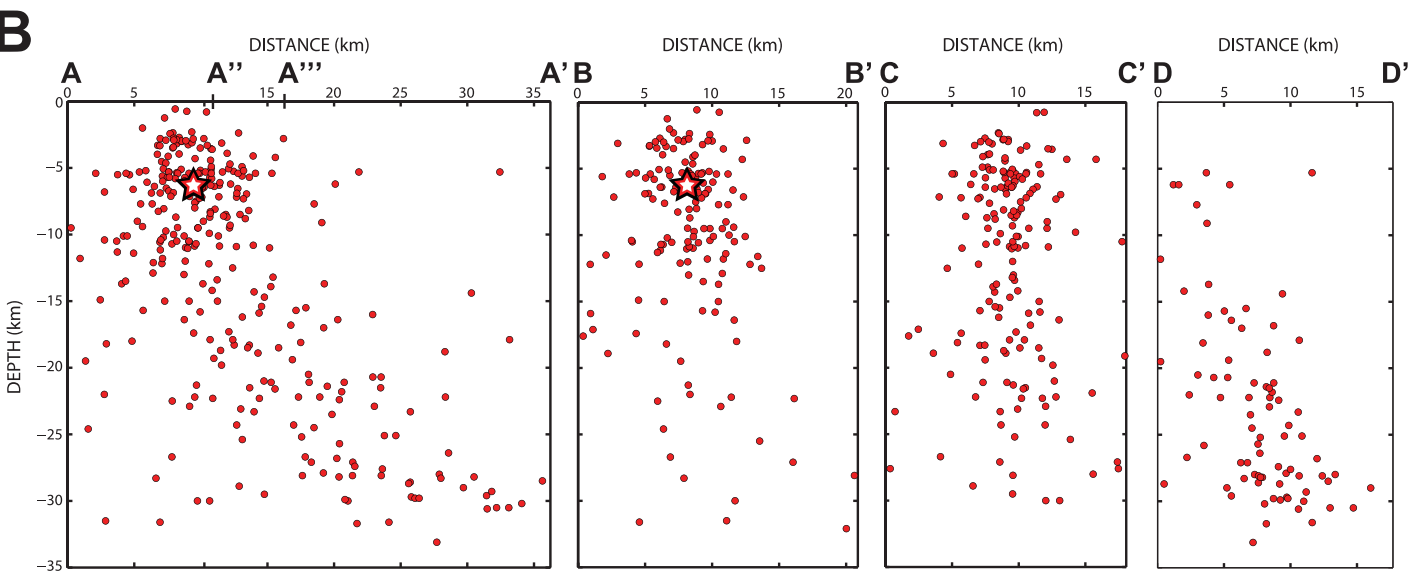

FIGURE 13 A) The earthquake activity between 30 July 2005 and 31 August 2005. See Table 1 for the focal mechanism solutions. The epicenter locations were re-calculated using data from the Kandilli Observatory and Earthquake Research Institute of Turkey's catalogue. B) Earthquake depth sections. See Figure 13A for the section line. 


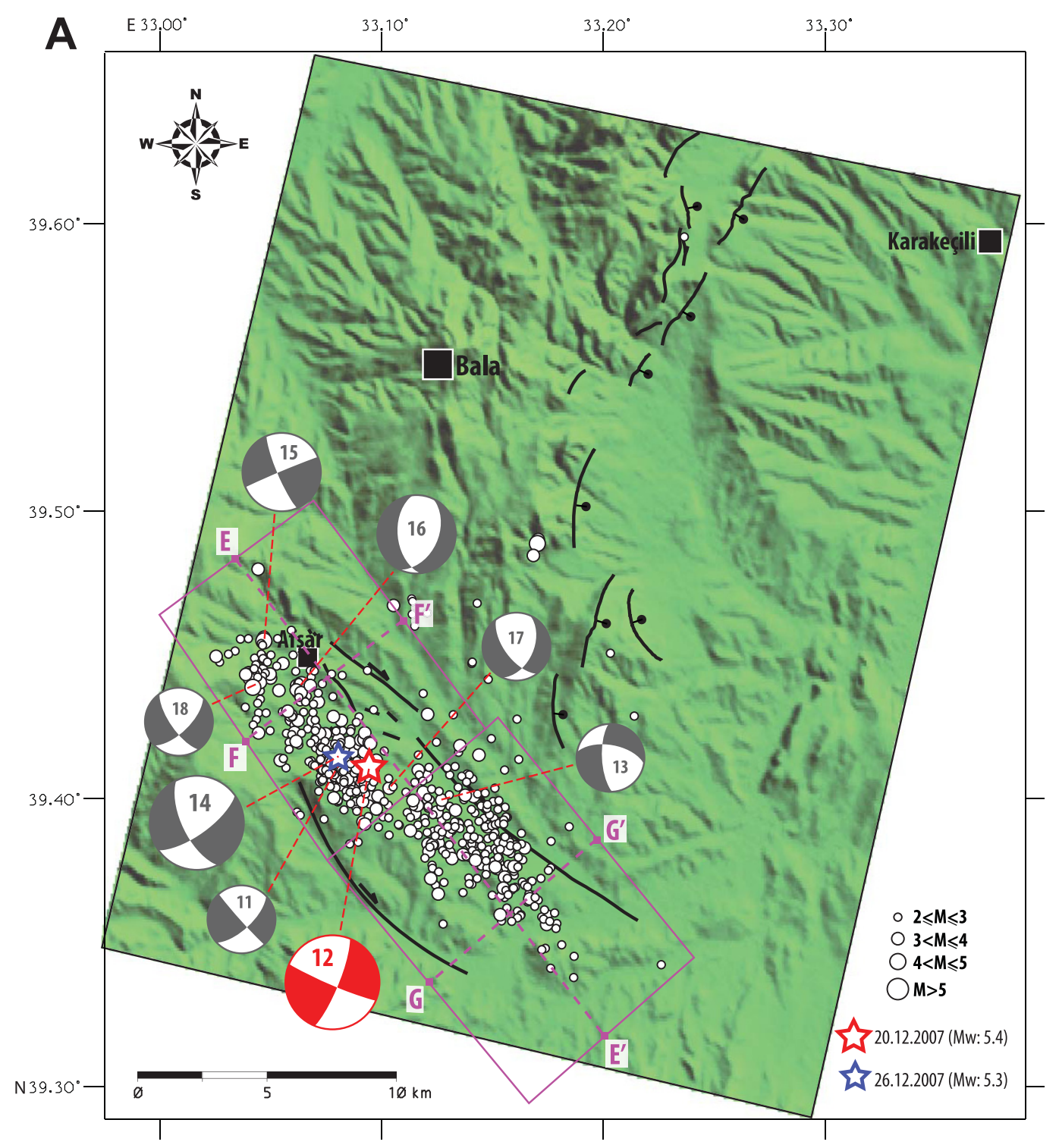

B
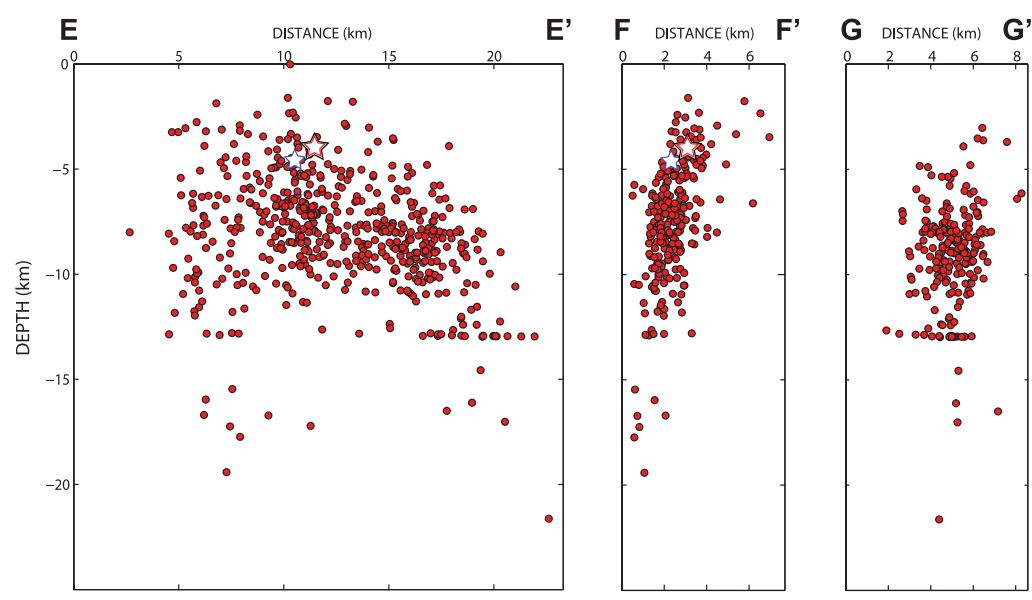

FIGURE 14 A) The main shock and its aftershocks recorded by AnkNET from 20 December 2007 to 10 October 2008. See Table 1 for the focal mechanism solutions. B) Earthquake depth sections. See Figure 14A for the section lines. 
A
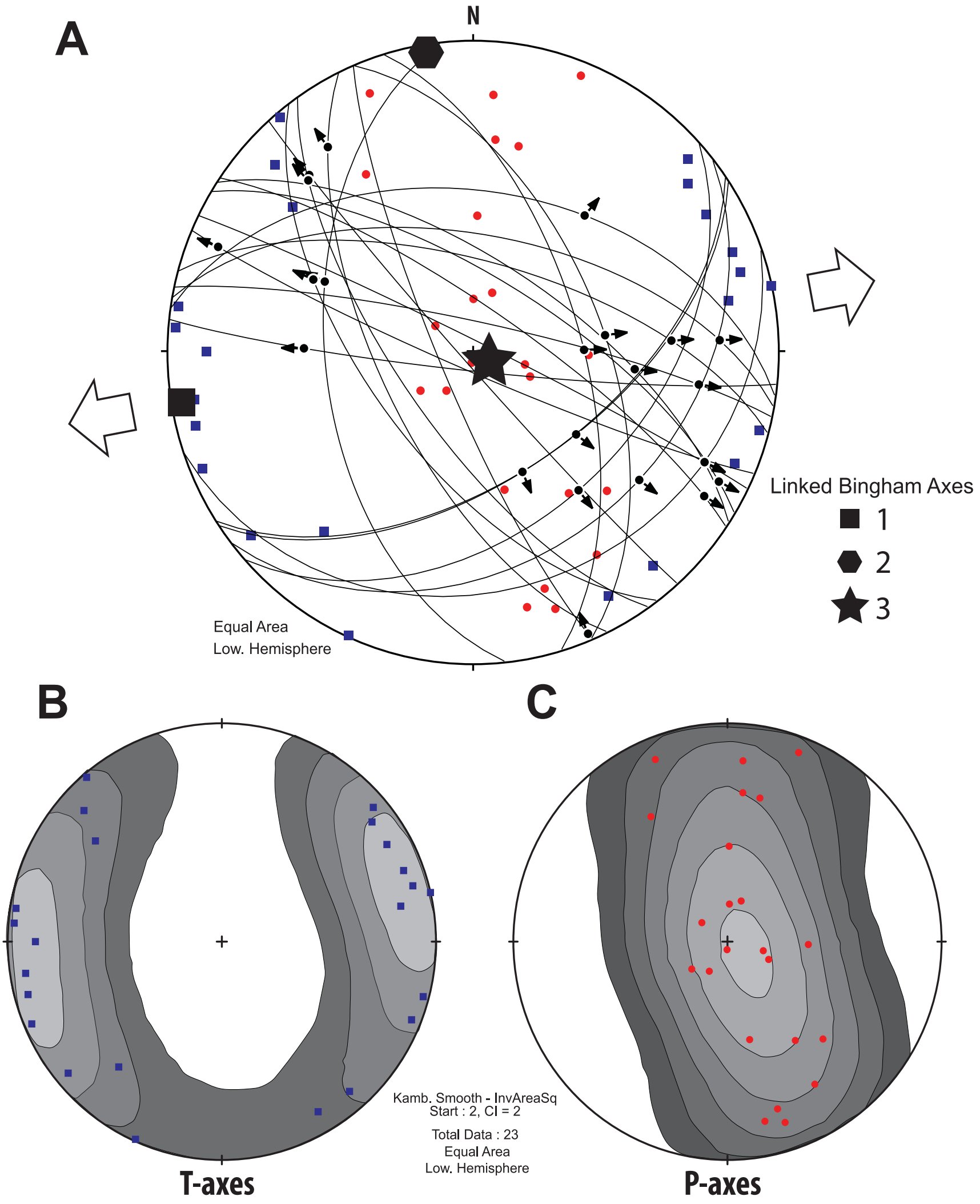

FIGURE 15 A) Analysis of fault slip data. The linked Bingham axes are $1: 4^{\circ} / 261^{\circ}$ (extension axis); $2: 3^{\circ} / 351^{\circ} ; 3: 85^{\circ} / 118^{\circ}$ (shortening axis) (plunge/ trend). Contoured diagrams of $\mathrm{B}$ ) the extension axes and $\mathrm{C}$ ) the shortening axes. 
December 2007 main shock and its aftershocks have a NW-SE trend (Fig. 11C; Fig. 14A). These clusters led some researchers to suggest right and left lateral strike-slip conjugate faults are active in the Bala region (Dirik et al., 2008; Kalafat et al., 2008; Çubuk and Taymaz, 2009; Koçyiğit, 2009; Tan et al., 2010). On the other hand, after the field observations following the 30 July 2005 main shock, Kasapoğlu et al. (2005) reported that the earthquake was related to normal faults with a small component of left lateral strike-slip.
The main earthquake and aftershock relocations as well as focal mechanism solutions, together with new detailed geological observations and seismic reflection studies, lead us to a different interpretation of the Bala earthquakes. We suggest that the main shocks of both the 2005 and the 2007 events occurred on the same right lateral strike-slip fault, the ARF, as shown by the identical fault mechanism solutions having a $\mathrm{N} 59^{\circ} \mathrm{W}$ trending fault plane. The aftershock distribution of the 2005 main shock and some of

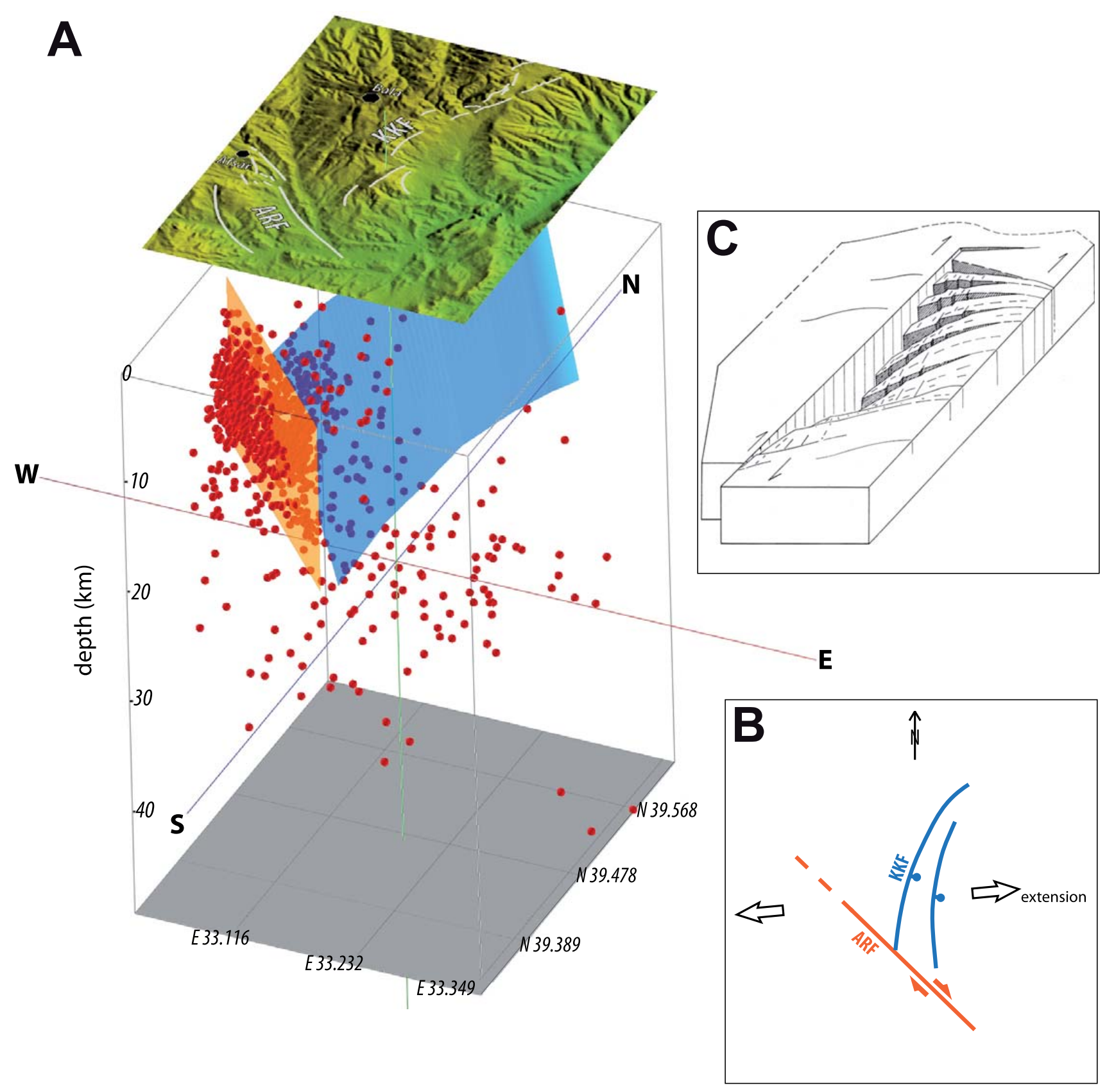

FIGURE 16 A) 3D perspective view of the proposed model. Red spheres show the earthquake hypocenters; orange and blue planes represent the approximate position of the ARF and KKF, respectively. B) Simplified map view of the model. KKF: Karakeçili fault, ARF: Af ar fault. C) Model for normal faulting at strike-slip fault-terminations after Kingma (1958). 
TABLE 1 Fault kinematic data obtained from nodal planes of the focal mechanism solutions and from field observations related to the Af ar and Karakeçili Faults in the Bala region (planes are displayed using the right-hand rule)

\begin{tabular}{lrrrrrl}
\hline & \multicolumn{2}{c}{ Fault plane } & \multicolumn{2}{c}{ Striae } & & \\
\cline { 2 - 4 } $\mathrm{N}^{\text {o }}$ & Strike $\left({ }^{\circ}\right)$ & Dip $\left(^{\circ}\right)$ & Trend $\left({ }^{\circ}\right)$ & Plunge $\left(^{\circ}\right)$ & Sense of slip & \\
\hline 1 & 303 & 66 & 96 & 45 & Normal & \\
2 & 301 & 70 & 117 & 10 & Normal & \\
3 & 343 & 61 & 89 & 60 & Normal & \\
4 & 278 & 47 & 40 & 42 & Normal & \\
5 & 57 & 56 & 128 & 54 & Normal & \\
6 & 304 & 78 & 122 & 12 & Normal & \\
7 & 296 & 87 & 115 & 17 & Normal & Focal mechanism \\
8 & 285 & 66 & 87 & 35 & Normal & solution data (see \\
9 & 96 & 85 & 271 & 44 & Normal & Fig. 13; Fig. 14; \\
10 & 282 & 82 & 98 & 26 & Normal & Table 1 for the \\
11 & 138 & 87 & 317 & 23 & Normal & locations) \\
12 & 113 & 85 & 292 & 11 & Normal & \\
13 & 280 & 59 & 87 & 20 & Normal & \\
14 & 154 & 65 & 324 & 20 & Normal & \\
15 & 157 & 81 & 157 & 2 & Reverse & \\
16 & 174 & 50 & 295 & 46 & Normal & \\
17 & 143 & 62 & 294 & 43 & Normal & \\
18 & 145 & 70 & 316 & 24 & Normal & \\
\hline Fig. 3A & 48 & 43 & 142 & 43 & Normal & \\
Fig. 3B & 71 & 24 & 115 & 17 & Normal & Field data (see Fig. 2 \\
Fig. 3C & 52 & 33 & 127 & 32 & Normal & for the locations) \\
Fig. 3D & 56 & 56 & 157 & 56 & Normal & \\
Fig. 3E & 337 & 55 & 83 & 54 & Normal & \\
\hline & & & & & & \\
\hline
\end{tabular}

the focal mechanism solutions indicate that the normal faulting corresponds with the NNE trending of the Karakeçili fault (KKF). We infer that the 2005 main shock triggered the seismic activity on the KKF. It can be concluded that the northwestern tip of the Tuzgölü fault zone represented by the Afşar fault, is terminated by an extensional system corresponding to the oblique-normal fault segments of the KKF in a similar fashion to the model for strike-slip fault terminations proposed by Kingma (1958) (Fig. 16).

\section{ACKNOWLEDGMENTS}

This paper is a result of "The geological and seismological investigation on the internal deformation of Anatolian Plate around Ankara (06B4343011)" project which is supported by Ankara University and "The geological and geophysical investigation of the active faults around Ankara (TUJJB-UDP-02-10)" project supported by National Union of Geodesy and Geophysics of Turkey (TUJJB), National Earthquake Programme (UDP).

Authors thank Yücel Güney, Muammer Tün, Emrah Pekkan, and Serkan Kahraman (Anadolu University) for their help in seismic reflection studies. We also thank Jesús Galindo-Zaldivar and an anonymous reviewer for their constructive criticism.

\section{REFERENCES}

Akçay, A.E., Dönmez, M., Kara, H., Yergök, A.F., Esentürk, K., 2008. Geological map of the Kırşehir-J30 quadrangle (1/100000 scaled). General Directorate of Mineral Research and Exploration, Ankara (Turkey).

Ambraseys, N.N., Finkel, C.F., 1995. Seismicity of Turkey and adjacent areas, a historical review, 1500-1800. İstanbul, Eren Yayıncılık ve Kitapçılık Ltd, 224pp.

Barka, A., Reilinger, R., 1997. Active tectonics of the Eastern Mediterranean region: deduced from GPS, neotectonic and seismicity data. Annali Di Geofisica, 40(3), 587-610.

Başokur, A.T., Gökten, E., Seyitoğlu, G., Varol, B., Ulugergerli, E., Işık, V., Candansayar, E., Tokgöz, E., 2002. The mechanisms of the 03.02.2002 Çay (Afyon) earthquake, causes of the damage, and the seismic activity of the region in the light of the geological and geophysical studies (in Turkish). Ankara, Ankara University, Faculty of Engineering, 56pp. 
Çıvgın, B., Kaypak, B., 2012. Investigation of one-dimensional crustal seismic velocity structure of Ankara and surroundings (in Turkish with English abstract). Yerbilimleri, 33(2), 131150.

Çubuk, Y., Taymaz, T., 2009. Time domain moment tensor analysis of 2005-2008 Bala (Ankara) earthquakes. Ankara, 62nd Geological Congress of Turkey, Abstract, 780-781.

Dewey, J.F., Hempton, M.R., Kidd, W.S.F., Saroglu, F., Şengör, A.M.C., 1986. Shortening of continental lithosphere: the neotectonics of Eastern Anatolia - a young collision zone. In: Coward, M.P., Ries, A.C. (eds.). Collision Tectonics. London, Geological Society, Special Publication, 3-36.

Dirik, K., Özsayın, E., Kutluay, A., 2008. Source of the seismic activity in the south of Ankara (central Anatolia) during last three years. Ankara, 61st Geological Congress of Turkey, Abstract, 76-77.

Emre, Ö., Duman, T.Y., Doğan, A., Özalp, S., Tokay, F., Kuşçu, İ., 2003. Surface faulting associated with the Sultandağ 1 earthquake (Mw 6.5) of 3 February 2002, southwestern Turkey. Seismological Research Letters, 74(4), 382-392.

Erol, O., 1954. Geology of Ankara and its surroundings (in Turkish). General Directorate of Mineral Research and Exploration of Turkey Report, 2491, unpublished, 306pp.

Esat, K., Çıvgın, B., Kaypak, B., Işık, V., Seyitoğlu, G., 2009. The nature of the Bala (Ankara) faults causing earthquakes and their meaning within the general neotectonic framework in the light of the geological and seismological data. Ankara, 62nd Geological Kurultai of Turkey, Abstract, 810-811.

Kalafat, D., Kekovali, K., Pinar, A., 2008. The 30 July 2005 $(\mathrm{Mw}=5.4)$ and the 20-26 December $2007(\mathrm{Mw}=5.5 ; \mathrm{Mw}=5.3)$ Afsar-Bala (Ankara) earthquake series in central Turkey. Geophysical Research Abstracts, 10, EGU2008-A-09923.

Kasapoğlu, K.E., Öztürk, E., Tetik, Ç., Bay, A., 2005. Site investigation report of the 31 July 2005 Bala (Ankara) earthquake (in Turkish). Ankara, Hacettepe University, Department of Geological Engineering, 23pp.

Kikuchi, M., Kanamori, H., 1991. Inversion of complex body waves III. Bulletin of the Seismological Society of America, 81, 2335-2350.

Kingma, J.T.,1958. Possible of Piercement structures, local unconformities, and secondary basins in the Eastern Geosyncline, New Zealand. New Zealand Journal of Geology and Geophysics, 1, 269-274

Kocaefe, S.S., Ataman, G., 1982. Actual tectonics of the western Anatolia (in Turkish with English abstract). Yerbilimleri, 9, 149-162.

Koçyiğit, A., 1991. An example of an accretionary forearc basin from northern Central Anatolia and its implications for the history of subduction of Neo-Tethys in Turkey. Geological Society of America Bulletin, 103, 22-36.

Koçyiğit, A., 2003. General tectonic characteristics and seismicity of Ankara region (in Turkish with English abstract). Turkish Association of Petroleum Geologists Bulletin, 5 (Special Publications), 1-26.

Koçyiğit, A., 2009. Seismicity of Ankara and source of the 2005-
2007 Afşar (Bala-Ankara) earthquakes (in Turkish with English abstract). Harita Dergisi, 141, 1-12.

Koçyiğit, A., Özacar, A.A., 2003. Extensional neotectonic regime through the NE edge of the outer Isparta Angle, SW Turkey: new field and seismic data. Turkish Journal of Earth Sciences, 12, 67-90.

Koçyiğit, A., Türkmenoğlu, A., Beyhan, A., Kaymakçı, N., Akyol, E., 1995. Post-collisional tectonics of EskisehirAnkara-Çankiri segment of Izmir-Ankara-Erzincan suture zone (IAESZ): Ankara orogenic phase. Turkish Association of Petroleum Geologists Bulletin, 6(1), 69-86.

Marrett, R., Allmendinger, R.W., 1990. Kinematic analysis of fault-slip data. Journal of Structural Geology, 12(8), 973-986.

McKenzie, D., 1972. Active tectonics of the Mediterranean region. Geophysical Journal of the Royal Astronomical Society, 30, 109-185.

Özsayın, E., Dirik, K., 2007. Quaternary activity of the Cihanbeyli and Yeniceoba Fault Zones: İnönü-Eskişehir Fault System, central Anatolia. Turkish Journal of Earth Sciences, 16, 471492.

Rojay, B., Karaca, A., 2008. Post-Miocene deformation in the south of the Galatean Volcanic Province, NW of central Anatolia (Turkey). Turkish Journal of Earth Sciences, 17, 653-672.

Rowland, S.M., Duebendorfer, E.M., Schiefelbein, I.M., 2007. Structural analysis and synthesis: a laboratory course in structural geology. Oxford, Blackwell Publishing, 301pp.

Saraç, G., 2003. Vertebrate fossil locations of Turkey (in Turkish). General Directorate of Mineral Research and Exploration of Turkey Report, 10609, unpublished, 218pp.

Seyitoğlu, G., Scott, B.C., 1991. Late Cenozoic crustal extension and basin formation in west Turkey. Geological Magazine, 128, 155-166.

Seyitoğlu, G., Scott, B.C., 1996. The cause of N-S extensional tectonics in western Turkey: tectonic escape vs back-arc spreading vs orogenic collapse. Journal of Geodynamics, 22(1-2), 145-153.

Seyitoğlu, G., Kazancı, N., Karadenizli, L., Şen, Ş., Varol, B., Karabıyıkoğlu, T., 2000. Rockfall avalanche deposits associated with normal faulting in the NW of Çankırı basin: implications for the postcollisional tectonic evolution of the Neo-Tethyan suture zone. Terra Nova, 12, 245-251.

Seyitoğlu, G., Aktuğ, B., Karadenizli, L., Kaypak, B., Şen, Ş., Kazancı, N., Işık, V., Esat, K., Parlak, O., Varol, B., Saraç, G., İleri, İ., 2009a. A Late Pliocene - Quaternary pinched crustal wedge in NW central Anatolia, Turkey: a neotectonic structure accommodating the internal deformation of the Anatolian Plate. Geological Bulletin of Turkey, 52(1), 121154.

Seyitoğlu, G., Kaypak, B., Işık, V., Esat, K., Çıvgın, B., 2009 b. Earthquake Monitoring Network of Ankara (ANKNET). Kocaeli (Turkey), Kocaeli University, International Earthquake Symposium Abstracts, 102.

Sokos, E., Zahradnik, J., 2008. ISOLA a Fortran code and a Matlab GUI to perform multiple-point source inversion of 
seismic data. Computers and Geosciences, 34, 967-977.

Soysal, H., Sipahioğlu, S., Kolçak, D., Altınok, Y., 1981. Earthquake catalogue of Turkey and its surroundings (in Turkish with English abstract). The Scientific and Technological Research Council of Turkey Report, TBAG 341, unpublished, 87pp.

Şaroğlu, F., Emre, Ö., Boray, A., 1987. The active faults and seismicity of Turkey (in Turkish). General Directorate of Mineral Research and Exploration of Turkey Report, 8174, unpublished, 394pp.

Şengör, A.M.C., 1979. The North Anatolian transform fault: its age, offset and tectonic significance. London, Journal of the Geological Society, 136, 269-282.

Şengör, A.M.C., 1980. Fundamentals of the neotectonics of Turkey (in Turkish). The Geological Society of Turkey Conference Series, 2, 40pp.

Şengör, A.M.C., Görür, N., Şaroğlu, F., 1985. Strike-slip faulting and related basin formation in zones of tectonic escape: Turkey as a case study. The Society of Economic Paleontologists and Mineralogists, 37 (Special Publications), 227-264.

Tan, O., Tapırdamaz, M.C., Ergintav, S., İnan, S., İravul, Y., Saatçılar, R., Tüzel, B., Tarancıoğlu, A., Karakısa, S., Kartal, R.F., Zünbül, S., Yanık, K., Kaplan, M., Şaroğlu, F., Koçyiğit, A., Altunel, E., Özel, N.M., 2010. Bala (Ankara) earthquakes: implications for shallow crustal deformation in central Anatolian section of the Anatolian Platelet (Turkey). Turkish Journal of Earth Sciences, 19, 449-471.
Taymaz, T., Tan, O., 2001. Source parameters of June 6, 2000 Orta-Çankırı and December 15, 2000 Sultandağ-Akşehir earthquakes $(\mathrm{Mw}=6.0)$ obtained from inversion of teleseismic P- and SH- body-waveforms. Symposia on Seismotectonics of the North-Western Anatolia-Aegean and Recent Turkish Earthquakes, İstanbul, Extended Abstract, 96-107.

Toksöz, M.N., Kuleli, S., Gürbüz, C., Kalafat, D., Bekler, T., Zor, E., Yılmazer, M., Öğüitçü, Z., Schultz, C.A., Harris, D.B., 2003. Calibration of regional seismic stations in the Middle East with shots in Turkey. Arizona, Proceedings of 25th Annual DoD/DOE Seismic Research Review, 162-171.

Türkmen, İ., Özkul, M., 1999. Sedimentology and evaporite genesis of Neogene continental sabkha playa complex, Karakeçili basin, central Anatolia, Turkey. Carbonates and Evaporites, 14(1), 21-31.

Waldhauser, F., Ellsworth, W.L., 2000. A double-difference earthquake location algorithm: Method and application to the northern Hayward fault, California. Bulletin of the Seismological Society of America, 90, 1353-1368.

Waldhauser, F., 2001. hypoDD - A program to compute doubledifference hypocenter locations. U.S. Geological Survey Open-File Report, 01-113.

Zahradnik, J., Serpetsidaki, A., Sokos, E., Tselentis, G.A., 2005. Iterative deconvolution of regional waveforms and a doubleevent interpretation of the 2003 Lefkada earthquake, Greece. Bulletin of the Seismological Society of America, 95, 159172.

Manuscript received August 2010;

revision accepted January 2014;

published Online February 2014. 


\section{APPENDIX I}

\section{Seismic Data Acquisition}

Seismic Equipment: Geometrics with 4 Geodes (96 channels). $14 \mathrm{~Hz}$ vertical geophones.

Seismic Source: P-Gun with 36 fusels.

Source-Receiver Design: Walk-Away (Roll-Along the Cable) technique.

Number of Shots: Lines: Çatalçeşme (KKF): 17, Üç Ağıl (ARF):

21 shots.

Number of Receivers: Lines: Çatalçeşme (KKF): 82, Üç Ağıl (ARF): 96 geophones.

Shot Interval: Lines: Çatalçeşme (KKF): 50, Üç A ̆̆l (ARF): 25 meters.

Receiver Interval: Lines: Çatalçeşme (KKF): 10, Üç A ̆̆ll (ARF): 5 meters.

Sampling Interval: Lines: Çatalçeşme (KKF): 1, Üç Ağıl (ARF): 0.5 milliseconds.

Recording Time: Lines: Çatalçeşme (KKF): 4, Üç Ağıl (ARF): 2 seconds.

\section{Seismic Data Processing}

Software: W_Geosoft Visual_SUNT v6.6.6. The processing sequences are:

1) Geometry Definition

2) Static Correction (Elevation)

3) Filter (Trapezoidal: 1, 5, 90, 100 Hertz)

4) Gain (AGC: Window: 0.5 seconds)

5) Trace Edit

6) First-Break Mute

\section{7) Ground-Roll Mute}

8) Sort (Major Key: CDP, Minor Key: Signed-Offset)

9) Velocity Analysis (at 6 CDP Stations)

10) Stack

11) Time-to-Depth Conversion

12) Lateral Smoothing (Weights: $0.25,0.5,1,0.5,0.25$ ) 